\title{
Aberrant Activity of Histone-Lysine N-Methyltransferase 2 (KMT2) Complexes in Oncogenesis
}

\author{
Elzbieta Poreba ${ }^{1, *(\mathbb{D})}$, Krzysztof Lesniewicz ${ }^{2}$ and Julia Durzynska ${ }^{1, *(\mathbb{D}}$ \\ 1 Institute of Experimental Biology, Faculty of Biology, Adam Mickiewicz University, \\ ul. Uniwersytetu Poznańskiego 6, 61-614 Poznań, Poland \\ 2 Department of Molecular and Cellular Biology, Institute of Molecular Biology and Biotechnology, \\ Faculty of Biology, Adam Mickiewicz University, ul. Uniwersytetu Poznańskiego 6, 61-614 Poznań, Poland; \\ lesniew@amu.edu.pl \\ * Correspondence: eporeba@amu.edu.pl (E.P.); juliadur@amu.edu.pl (J.D.); Tel.: +48-61-829-5857 (E.P.)
}

Received: 19 November 2020; Accepted: 6 December 2020; Published: 8 December 2020

\begin{abstract}
KMT2 (histone-lysine N-methyltransferase subclass 2) complexes methylate lysine 4 on the histone $\mathrm{H} 3$ tail at gene promoters and gene enhancers and, thus, control the process of gene transcription. These complexes not only play an essential role in normal development but have also been described as involved in the aberrant growth of tissues. KMT2 mutations resulting from the rearrangements of the KMT2A (MLL1) gene at 11q23 are associated with pediatric mixed-lineage leukemias, and recent studies demonstrate that KMT2 genes are frequently mutated in many types of human cancers. Moreover, other components of the KMT2 complexes have been reported to contribute to oncogenesis. This review summarizes the recent advances in our knowledge of the role of KMT2 complexes in cell transformation. In addition, it discusses the therapeutic targeting of different components of the KMT2 complexes.
\end{abstract}

Keywords: histone-lysine N-methyltransferase 2; COMPASS; COMPASS-like; H3K4 methylation; oncogenesis; cancer; epigenetics; chromatin

\section{Introduction}

In the past two decades, efforts have been made to create a comprehensive and universal description of common traits of cancer cells. This gave rise to a new term-cancer hallmark-that reflects each of the intrinsic characteristics of a cancer cell not found in normal cells. Although a vigorous debate is still taking place, it can be agreed upon that cancer cells are independent of growth and antigrowth stimuli. These cells can evade apoptosis and replicate in a limitless manner and, hence, become immortal. Cancer cells also induce angiogenesis for a better supply of nutrients and are capable of spreading to different sites of the body (metastasis). Furthermore, they can reprogram energy metabolism, escape the immune response system, and promote inflammation. The underlying conditions are mutations and genome instability, which allow for the establishment of all cancer hallmarks [1-4]. However, the genetic landscape of cells undergoing transformation is only one part of the story, as the acquired knowledge of epigenetic modifications has helped us understand their crucial importance and contribution to virtually all classic hallmarks of cancer [5]. Recent studies based on the high-throughput sequencing of genomes, epigenomes, and transcriptomes have provided us with enormous data pointing to the relationship between cancer development and mutations in genes encoding epigenetic modifiers. Abnormal histone methylation resulting from gene mutation, translocation, or the deregulated expression of histone methyltransferases has been frequently observed in cancers. Depending on the histone and the modified residue, the process of methylation plays various 
biological roles. The methylation of lysine 4 on histone $\mathrm{H} 3$ is associated with transcriptional activation and is catalyzed by histone methyltransferases classified as KMT2s (lysine-specific methyltransferases subclass 2) [6]. H3K4 trimethylation (H3K4me3) is characteristic of accessible gene promoters, whereas H3K4 monomethylation (H3K4me1) occurs in enhancer elements [7-9].

This review aims to present the most recent advances in our understanding of the structure and role of KMT2 complexes in cellular transformation. The oncogenic outcomes of mutations in KMT2s, as well as in the core subunits of the KMT2 complexes, are discussed. In addition, a number of molecular strategies targeting different components of the KMT2 complexes with anticancer therapeutic potential are described in detail.

\section{Structure of the KMT2 Complexes}

KMT2s are the main H3K4 methyltransferases that regulate gene transcription. The KMT2 family is highly conserved in eukaryotes. While three subgroups of KMT2s, each with a single representative, are present in Drosophila melanogaster - trithorax (Trx), trithorax-related (Trr), and Set1-two paralogs of each subgroup appeared in humans during evolution. Human cells contain two Trx-related KMT2s (KMT2A and KMT2B), two Trr-related KMT2s (KMT2C and KMT2D), and two Set1-related KMT2s (KMT2F and KMT2G) (Figure 1). Although KMT2E was initially classified under the KMT2 family, it was identified to be more homologous to yeast SET3 (SET domain-containing protein 3) and SET4 (SET domain-containing protein 4) and Drosophila CG9007 (encoding the protein “UpSET") [10-12]. Moreover, unlike the other KMT2s present in humans, KMT2E does not exhibit intrinsic methyltransferase activity toward histone substrates [12].

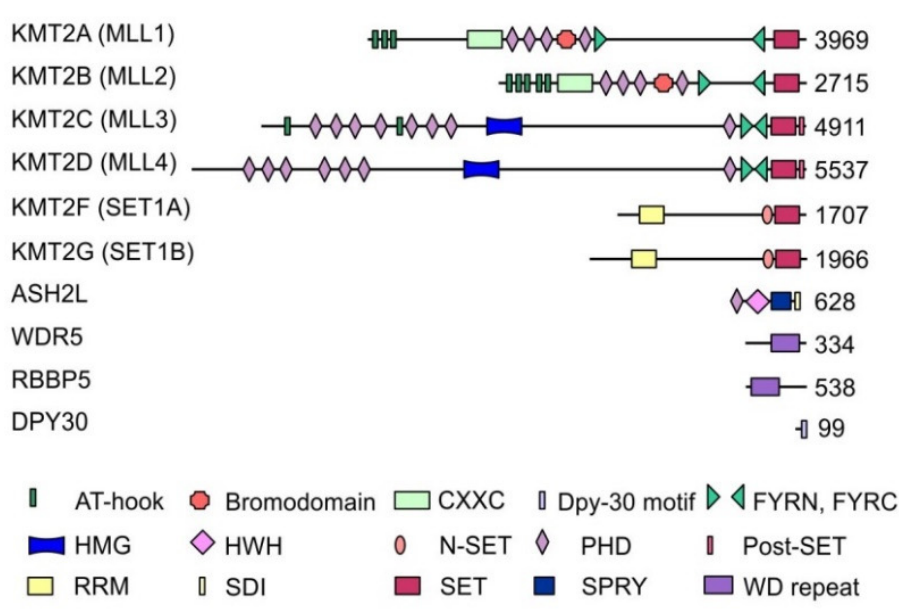

a

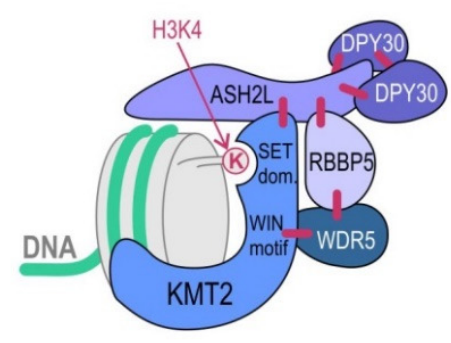

b

Figure 1. (a) Domain structure of the KMT2 family and core subunits of the KMT2 complexes. The numbers indicate the number of amino acids. KMT, histone-lysine N-methyltransferase; ASH2L, absent, small, or homeotic 2-like; DPY30, Dumpy-30; RBBP5, retinoblastoma-binding protein 5; WDR5, WD repeat-containing protein 5; AT-hook, adenosine-thymidine-hook; CXXC, Zinc finger-CXXC domain; FYRN/FYRC, phenylalanine and tyrosine-rich region ( $\mathrm{N}$ - and $\mathrm{C}$-terminal); HMG, high mobility group; HWH, helix-wing-helix domain; N-SET, N-terminal of SET; PHD, plant homeodomain; Post-SET, C-terminal of SET; RRM, RNA recognition motif; SDI, Sdc1-Dpy-30 interaction; SET, Su(var)3-9, Enhancer-of-zeste and Trithorax; SPRY, SPla and the ryanodine receptor domain; and WD repeat, tryptophan-aspartic acid repeat. (b) The structure of the KMT2 complex. The enzyme and the core subunits of the complex are shown in the diagram. The interactions between individual subunits are marked with blue lines. Subunits specific to individual KMT2 complexes, not shown in the figure, interact with the amino terminus of the KMT2s. WIN motif, WDR5 interaction motif. 
The KMT2s function in large multi-subunit complexes, which, in vertebrates, are often referred to as COMPASS or COMPASS-like complexes (COMplex of Proteins ASsociated with Set1). While there is one COMPASS complex in yeast, there are three in Drosophila and six closely related complexes in vertebrates, which contain one KMT2 methyltransferase unique to each complex, four core subunits commonly found in all KMT2 complexes, and additional complex-specific proteins (Table 1).

Table 1. Subunit composition of the mammalian KMT2 complexes.

\begin{tabular}{cccc}
\hline & $\begin{array}{c}\text { KMT2A or KMT2B } \\
\text { Complex }\end{array}$ & $\begin{array}{c}\text { KMT2C or KMT2D } \\
\text { Complex }\end{array}$ & $\begin{array}{c}\text { KMT2F or KMT2G } \\
\text { Complex }\end{array}$ \\
\hline Enzyme & KMT2A or KMT2B & KMT2C or KMT2D & KMT2F or KMT2G \\
\hline \multirow{5}{*}{ Core subunits } & ASH2L & ASH2L & ASH2L \\
& RBBP5 & RBBP5 & RBBP5 \\
& WDR5 & WDR5 & WDR5 \\
& DPY30 & DPY30 & DPY30 \\
Unique subunits & Menin & PTIP & CFP1 \\
& HCF1 or HCF2 & PA1 & WDR82 \\
& & NCOA6 & HCF1 \\
\hline
\end{tabular}

KMT, histone-lysine N-methyltransferase; ASH2L, absent, small, or homeotic 2-like; RBBP5, retinoblastoma-binding protein 5; WDR5, WD repeat-containing protein 5; DPY30, Dumpy-30; HCF1, host cell factor 1; PTIP, PAX transactivation-domain interacting protein; PA1, PTIP-associated 1; NCOA6, nuclear receptor coactivator 6; UTX, ubiquitously transcribed tetratricopeptide repeat, X chromosome; CFP1, CXXC finger protein 1; and WDR82, WD repeat-containing protein 82 .

The four core subunits-WDR5 (WD repeat domain 5), RBBP5 (retinoblastoma-binding protein 5), ASH2L (absent, small or homeotic 2-like), and DPY30 (Dumpy-30)-form a subcomplex that stably interacts with the KMT2 enzymes and stimulates KMT2 catalytic activity up to several hundred-fold $[13,14]$. A crystal structure analysis of the KMT2A complex has shown that the interaction of KMT2A with the core subunits (WDR5, RBBP5, and ASH2L) forces a conformational change in the SET domain of KMT2A, which is necessary to achieve a catalytically efficient form [14-17]. Biochemical and structural studies have demonstrated that the KMT2A complex is stabilized by direct interactions between KMT2A and WDR5 that bridges KMT2A to RBBP5. Furthermore, RBBP5 interacts with ASH2L, which binds the DPY30 protein. Although WDR5 is essential for regulating the activity of KMT2A, it is not responsible for the regulation of other KMT2s, and these KMT2s have been shown to be stimulated by the stable ASH2L-RBBP5 heterodimer that directly interacts with them [13]. The structure of the KMT2 complex is presented in Figure 1b.

In addition to their role in stabilizing and regulating KMT2 complexes, the core subunits of the WRAD subcomplex participate in the recruitment of these complexes to chromatin. The recruitment of KMT2 complexes to the genomic loci is also regulated by the unique complex-specific subunits that determine the functional diversity of these complexes. The three KMT2 groups of complexes differ in their sets of interacting proteins (Table 1). The additional subunits associated with the KMT2A/KMT2B complexes are Menin and HCF1/2 (host cell factors 1/2) [18,19]. Another protein that interacts with the KMT2A/KMT2B complexes is LEDGF (lens epithelium-derived growth factor, also known as PSIP1/p75). However, LEDGF is a substoichiometric component in these complexes and exhibits only a weak interaction with them through Menin [19-21]. PTIP (PAX transactivation domain-interacting protein), PA1 (PTIP-associated 1), NCOA6 (nuclear receptor coactivator 6), and UTX (ubiquitously transcribed tetratricopeptide repeat, X chromosome) interact specifically with KMT2C and KMT2D [22-24], while CFP1 (CXXC finger protein 1), WDR82 (WD repeat domain 82), and HCF1 (host cell factor 1) interact only with KMT2G and KMT2F [19,25].

In addition to the stable interaction with the complex-specific subunits, the KMT2 complexes dynamically interact with many transcription factors, including NFE2 (nuclear factor, erythroid 2) [26], USF1 (upstream transcription factor 1) [27], MEF2D (myocyte enhancer factor 2D) [28], NF-Y (nuclear 
transcription factor Y) [29], NF-E2 (nuclear transcription factor erythroid 2) [26,30], AP2 $\delta$ (activating protein 28) [31], MYC [32], OCT4 (octamer-binding transcription factor 4, also known as POU5F1) [33], NANOG [34], p53 [35-37], E2Fs [35,38,39], and PAX7 (Paired Box 7) [40]. These interactions of the KMT2 complexes are important for their context-dependent roles.

\section{Domain Structure of KMT2s}

All KMT2s contain an evolutionarily conserved catalytic SET domain. The acronym "SET" is derived from the first three proteins identified as harboring this domain in Drosophila-Su(var)3-9, Enhancer-of-zeste, and Trithorax [41]. SET domains catalyze the transfer of methyl groups from S-adenosyl-L-methionine onto the $\mathrm{N} \varepsilon$ group of a lysine in substrate proteins. Unlike other proteins in the KMT2 family, KMT2A and KMT2B have the consensus sites cleaved by taspase 1 , a threonine aspartase [38,42]. This cleavage generates two fragments of KMT2A/KMT2B proteins: a large amino-terminal fragment and a smaller carboxy-terminal fragment. These two fragments associate through the FY-rich N-terminal (FYRN) and FY-rich C-terminal (FYRC) domains to form a functional heterodimeric complex.

KMT2s contain specific domains for interaction with DNA, histones, and other proteins. KMT2A-KMT2D contain clusters of plant homeodomain (PHD) fingers, which are one of the epigenetic readers of H3K4me3. Although many PHD fingers are present in KMT2s, only PHD3 of KMT2A has been shown to bind H3K4me3 [43]. The other PHD fingers do not recognize methylated H3K4 and are instead involved in recognizing other histone modifications [44]; for example, PHD4-6 of KMT2D recognize nonmethylated or asymmetrically methylated arginine 3 of histone $\mathrm{H} 4$. Binding to H4R3me2a is important for the nucleosomal methyltransferase activity and localization of KMT2D. The PHD fingers of KMT2s also interact with other proteins. For example, PHD3 of KMT2A interacts with cyclophilin 33 (CYP33 or PPIE) [45]. CYP33 was shown to compete with PHD3 for binding with H3K4me3, thereby leading to the repression of KMT2A target genes [46]. PHD2 fingers of KMT2A and KMT2B have E3 ubiquitin ligase activity and were shown to ubiquitinate $\mathrm{H} 3$ and $\mathrm{H} 4$ histones in vitro [47]. The loss of PHD fingers in KMT2A due to genomic translocation in MLL-r leukemia is responsible for the transforming potential of the resulting fusion proteins, which indicates the role of PHD fingers in the correct recruitment of KMT2A into the genomic loci [48,49]. Furthermore, the CXXC zinc finger domain, the AT-hook region, and the high-mobility group I (HMG-I)-binding motif present in some KMT2s are involved in DNA binding. KMT2A-KMT2D contain LXXLL motifs (also known as NR boxes), characteristic for transcription factors and cofactors interacting with nuclear receptors. The number of NR boxes varies in different MLLs [50]. A characteristic future of the protein sequence of KMT2F and KMT2G is the presence of the C-terminal N-SET domain, which interacts with the ubiquitylated histone H2B and an RNA recognition motif (RRM). The domain structure of KMT2s is presented in Figure 1a.

\section{Substrate Specificity of KMT2 Complexes and Their Recruitment to Chromatin}

The KMT2 complexes differ in their specificity and genome-wide localization. Differences in their unique subunit composition and their interactions with transcriptional regulators determine the location of these complexes throughout the genome (Figure 2). The KMT2F/KMT2G complexes are highly enriched at gene promoters and responsible for the vast majority of $\mathrm{H} 3 \mathrm{~K} 4 \mathrm{di}$ - and trimethylation processes $[27,51]$. They are localized to distinct regions of chromatin and generally act in a nonredundant manner [25]. It was recently shown that KMT2F and KMT2G are responsible for broad H3K4me3 peaks and that KMT2G is functionally redundant to KMT2F at highly expressed genes in embryonic stem (ES) cells [52]. The KMT2A/KMT2B complexes are also important for H3K4 di- and trimethylation, but ChIP experiments showed that less than 5\% of global H3K4 trimethylation is KMT2A-dependent, and one of the well-characterized targets of KMT2A was identified to be HOX genes [53]. Moreover, KMT2A/KMT2B complexes have been shown to bind to de novo enhancers [54]. In contrast, the KMT2C and KMT2D complexes are responsible for H3K4 monomethylation (H3K4me1) and occupy enhancers enriched with this type of modification [54-56]. 

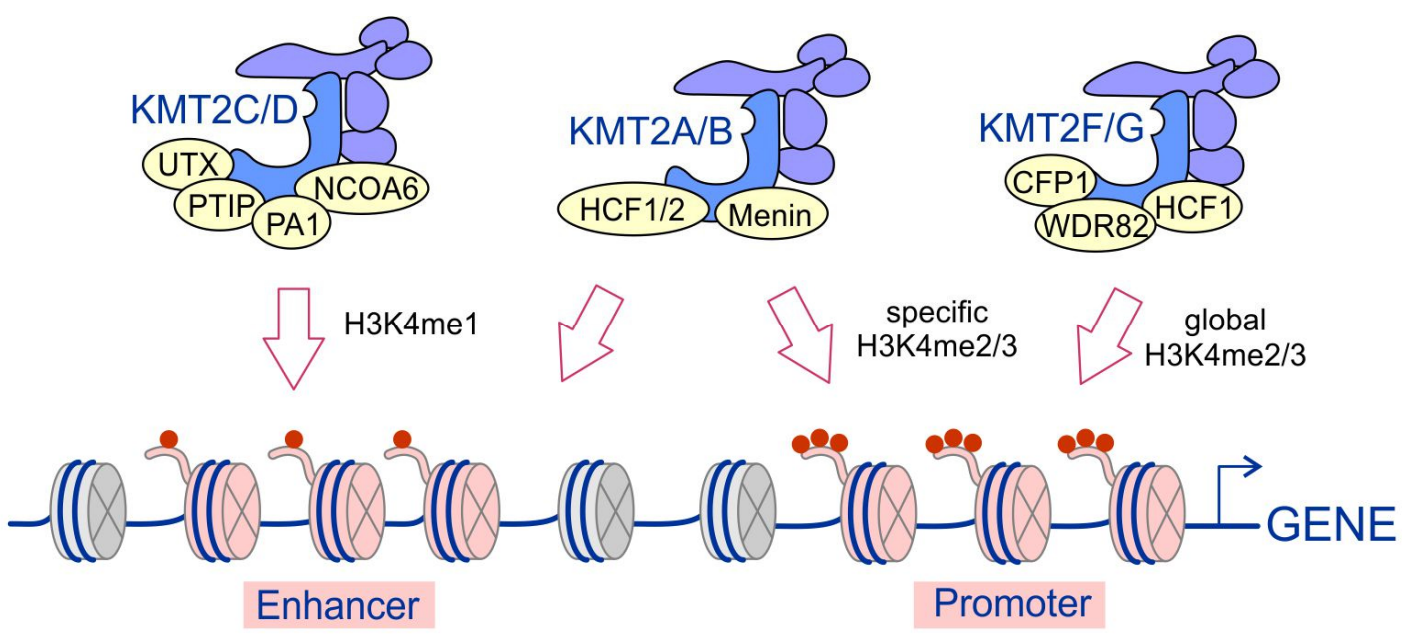

Figure 2. Specialization of COMPASS and COMPASS-like complexes in mammals. The KMT2F/KMT2G complexes, referred to as COMPASS complexes, are most similar to the yeast Set1 complex. These complexes are mainly responsible for bulk H3K4me3 genome-wide. The KMT2A/KMT2B and KMT2C/KMT2D complexes are referred to as COMPASS-like and are most similar to the Drosophila Trithorax complex and Drosophila Trithorax-related protein, respectively. KMT2A/KMT2B complexes are required for the $\mathrm{H} 3 \mathrm{~K} 4$ tri- and dimethylation in less than $5 \%$ of promoters and mainly regulate developmental genes. KMT2C/KMT2D complexes occupy enhancers and are responsible for H3K4 monomethylation.

The recruitment of KMT2 complexes to specific genomic loci is mediated by multiple mechanisms, including the interaction of these complexes with sequence-specific transcription factors, basal transcription factors, cofactors, and chromatin specified by histone modifications and the mechanisms of long noncoding RNAs (lncRNAs) (Figure 3). Both KMT2 core subunits and additional complex-specific subunits, as well as KMT2s, have been shown to interact with different transcription factors. For example, Menin, a unique subunit in KMT2A/KMT2B complexes, mediates their recruitment to specific genomic loci by interacting with estrogen receptor- $\alpha(E R \alpha)$ [57]. KMT2C and KMT2D interact through PTIP with the PAX family of transcription factors, including Pax2 (Paired Box 2) and Pax5 (Paired Box 5) [22,24], and through NCOA6 (ASC-2) with nuclear receptors such as the farnesoid $X$ receptor (FXR), which regulates the genes involved in bile acid homeostasis [58], as well as with the MAFA (MAF BZIP Transcription Factor A) and MAFB (MAF BZIP Transcription Factor B) transcription factors to regulate the functions of islet beta cells [59]. In addition, KMT2C/KMT2D complexes may be recruited by the tumor suppressor 553 by interaction with 53BP1 that binds to NCOA6 [36]. The subunits of the WRAD subcomplex also interact with many transcription factors. For instance, WDR5 binds to the pluripotency transcription factor OCT4 and recruits KMT2 complexes to mediate self-renewal and pluripotency of the ES cells [33]. OCT4 has also been shown to interact directly with KMT2F independently of WDR5 [51] and with ASH2L through SOX2. This recruitment mechanism of the KMT2 complexes was reported to be important for efficient cellular reprogramming of differentiated cells into induced pluripotent stem (iPS) cells [60]. Furthermore, the recruitment of these complexes onto the key developmental genes in ES cells is mediated by the core pluripotency factor NANOG that interacts with DPY30. NANOG cooperates with the activin-SMAD2/3 signaling pathway and was shown to coordinate the fate decisions of human ES cells by controlling H3K4me3 [34]. Another transcription factor that interacts with the KMT2 complexes is MYC. This interaction is mediated by ASH2L and has been found to control H3K27 modifications and regulate bivalent chromatin [32]. MYC interacts not only with ASH2L but, also, with WDR5. However, the interaction with WDR5 renders MYC recruitment to chromatin independent of other WRAD subunits [32,61]. The recruitment of the KMT2 complexes through ASH2L for controlling H3K4 methylation has also been shown for other transcription factors, such as USF1 (upstream transcription factor 1) [27], NF-Y (nuclear transcription 
factor Y) [29], NF-E2 (nuclear transcription factor erythroid 2) [26,30], MEF2D transcription factor [62], and Ap2delta (TFAP2D) [31,63].

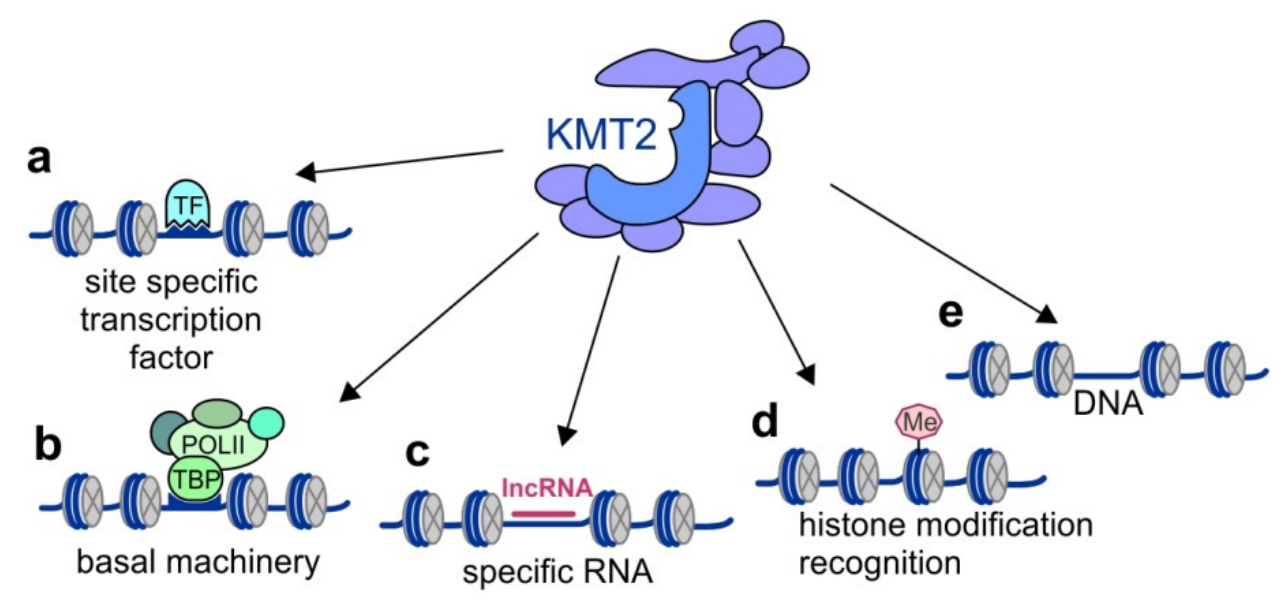

Figure 3. Mechanisms of H3K4 methyltransferase recruitment to chromatin. KMT2 complexes are recruited and stabilized on chromatin by a combination of mechanisms: (a) interactions with sequence-specific transcription factors, (b) association with the basal transcriptional machinery, (c) interaction with long noncoding RNAs (lncRNAs), (d) recognition of histone modification, and (e) direct interaction with DNA. For references, see the text.

Furthermore, KMT2 complexes can interact with RNA polymerase (RNAP) II and basal transcription factors. For example, WDR82 was found to directly interact with RNAP II phosphorylated at Ser 5 and mediate the recruitment of the KMT2F complex to transcription start sites [64]. KMT2A was shown to interact with RNAP II through an RNAP II-associated factor, hPaf1/PD2 [65].

Recent data indicate that the recruitment of KMT2 complexes to chromatin can also be mediated through their interactions with lncRNAs, which may act as a scaffold guiding the KMT2 complexes to specific genomic loci [66]. KMT2 complexes bind to lncRNAs via the WDR5 subunit, which, in turn, has been shown to interact with many lncRNAs through an RNA-binding pocket. The interaction of WDR5 with lncRNA HOTTIP (HOXA transcript at the distal tip), which regulates the expression of the HOXA gene cluster, was observed to be involved in the recruitment of WDR5/KMT2A complexes to the HOXA locus and, thus, promote H3K4 trimethylation and HOXA gene transcription. The expression of the HOXB cluster is also regulated by the interaction of KMT2s with a lncRNA. The HoxBlinc lncRNA regulating the HOXB cluster interacts with the SET domain of the KMT2A or KMT2F enzyme. This mechanism activates the anterior hoxb genes and, thus, promotes the differentiation of cardiogenic/hemogenic mesoderm [67].

KMT2 complexes can also directly interact with DNA, which allows them to function independently of transcription factors at some genomic loci. KMT2 methyltransferases contain DNA-binding domains, including the CXXC zinc finger domain, the AT-hook region, and the HMG-I-binding motif. The CXXC zinc finger domains present in KMT2A and KMT2B bind to nonmethylated CpG-containing DNA sequences [68-71]. The CXXC domain is absent from other KMT2 methyltransferases. However, it can be found in the CFP1 protein, a subunit specific to the KMT2F/KMT2G complexes, and is likely used by them for interacting directly with CpG-rich DNA [72,73]. The AT-hooks and HMG-I are small motifs that bind to the minor groove of AT-rich DNA sequences in a distorted or cruciform conformation [74]. The DNA-binding motifs present in KMT2 methyltransferases stabilize them on chromatin. Their functional importance has been demonstrated in structure-function studies, which showed that the DNA-binding domains, AT-hooks, and CXXC domain present in KMT2A are responsible for the transforming ability of the KMT2A fusion protein [75].

H3K4 methylation is recognized by reader proteins that transfer the information related to epigenetic modifications to the basal transcription machinery, thus promoting transcription. Several methylated 
H3K4 interactors have been identified so far (Figure 4). These interactors bind to methylated H3K4 via different domains, including PHD, tandem Tudor domain (TTD), double chromodomains (DCD), zinc finger $\mathrm{CW}$ (zf-CW), and the recently discovered CryptoTudor domain [8,76-78]. A PHD domain capable of binding to H3K4me3 was identified, for example, in TAF3 (TBP-associated factor 3), a TFIID component that plays an important role in the recruitment of the RNAP II complex to core promoters $[79,80]$. The chromatin remodeling complex NURF (nucleosome remodeling factor) is another important reader of H3K4me3 [81,82]. BPTF (Bromodomain PHD Finger Transcription Factor), a subunit of the NURF complex, has been shown to bind to H3K4me3, thereby coupling H3K4me3 to chromatin remodeling, as well as to maintain the patterns of HOX gene expression during development [82]. Other noteworthy proteins that are capable of reading the H3K4me3 modification include the ING (inhibitor of growth) family of proteins [83-85] and PHF13 [86] proteins. The CryptoTudor domain identified in the BRWD2/PHIP protein has been shown to interact both with H3K4me1 and KH3K4me3 [87]. BRWD2/PHIP was found at both enhancers marked by H3K4me1 and promoters enriched in H3K4me3 and is likely to control H3K27ac in bivalent chromatin [87].

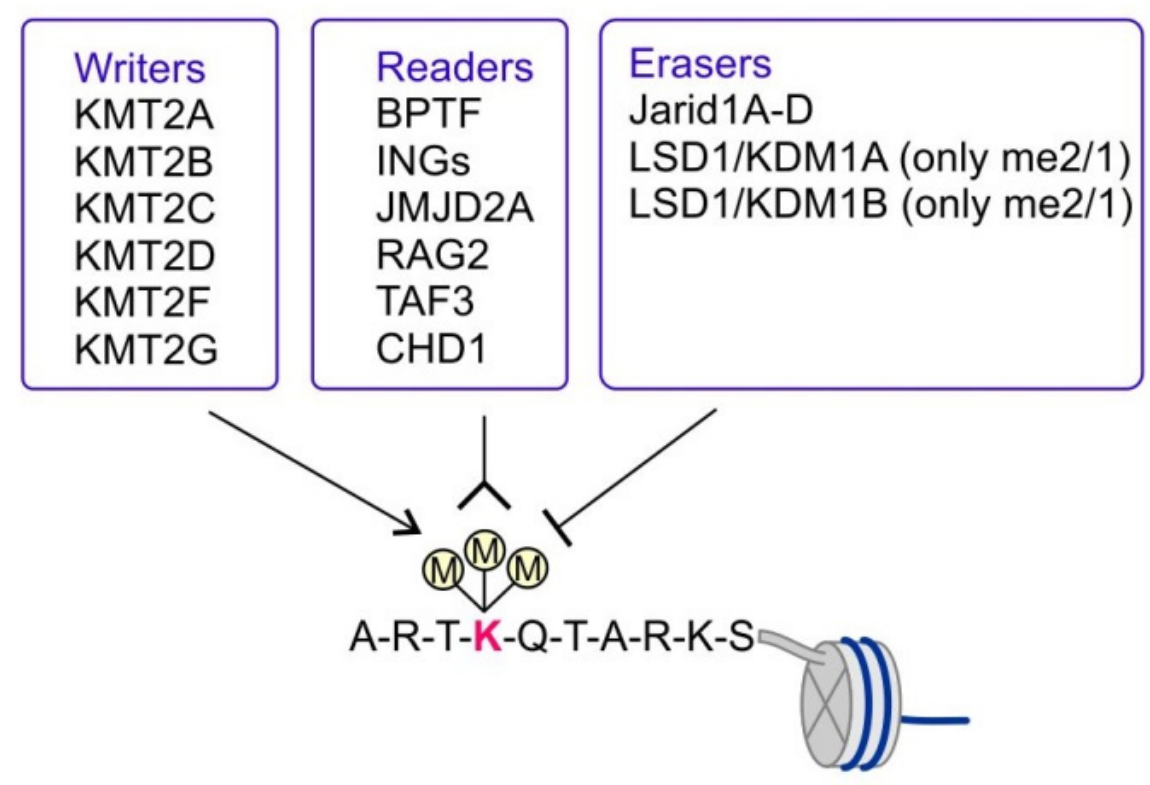

Figure 4. Known writers, readers, and erasers of H3K4 methylation.

Although the main substrate of the KMT2 complexes is lysine 4 of histone 3, nonhistone substrates of these enzymes have also been identified. KMT2F has been shown to methylate the HSP70 and YAP proteins, thus promoting tumorigenesis $[88,89]$. A recent study demonstrated that p53 may be a potential substrate of KMT2 family methyltransferases [90]. KMT2A-D and KMT2G have been shown to be capable of methylating p53 at K305 in in vitro tests; however, the physiological role of this modification has not yet been elucidated.

\section{Mutations in the KMT2 Family in Cancer}

The relationship between KMT2 complexes and oncogenesis was first demonstrated by the example of KMT2A, which is translocated to other fusion gene partners in approximately $10 \%$ of human leukemias [91]. Recent studies have shown that KMT2 mutations not only influence the development of neoplastic processes in leukemias but are also among the most common changes observed in human cancers and are associated with different types of solid tumors. 


\subsection{KMT2A (MLL1) and KMT2B (MLL2)}

Originally, the first somatic mutations linked to cancer development were described for the KMT2A gene located on chromosome 11q23 [92], which is rearranged with a considerable number of other translocation partner genes (TPGs) [93-95]. This translocation is possible because of frequent chromosomal double-stranded DNA (dsDNA) breaks that are not repaired in developing hematopoietic cells [96]. All KMT2A fusion proteins are coded by the first 8 to 13 exons of the KMT2A gene making up the C-terminal part of the hybrid protein and a variable number of fusion partner (FP) exons coding for the N-terminal part [97]. Normally, as a part of the COMPASS-like complex, KMT2A methylates H3K4 through its SET domain and, thus, regulates the transcription of target genes [98]. After the translocation of KMT2A to its FP, this domain is lost in all MLL-FPs. As of 2018, a total of 135 different KMT2A rearrangements have been identified, the majority of which are in-frame translocations resulting in functional gain-of-function (GOF) oncoprotein products displaying altered activities [99]. However, there are several most common genes fused with the KMT2A gene, accounting for an overwhelming majority of mixed-lineage leukemias (MLLs; 80-90\%), including MLL-AF4, MLL-AF9, MLL-ENL, MLL-PTD, MLL-AF10, and MLL-ELL [99-103] (Figure 5a,b). On the other hand, MLL-rearranged (MLL-r) leukemias account for approximately 10\% of all human leukemias [104]. Fusions with TPGs such as AF4, AF9, AF10, and ENL lead to the formation of MLL-r complexes, in which MLL-FPs directly interact with the H3K79 methyltransferase DOT1L (disruptor of telomeric silencing 1-like) and super elongation complex (SEC). These interactions lead to aberrant H3K79 methylation, thereby reshaping the gene expression pattern toward leukemic transformation [105-109]. Quite similarly, the MLL-ENL chimeric protein, along with its interacting proteins, including DOT1L, is capable of methylating H3K79 [110]. Due to KMT2A gene fusion, other histone amino acids can also be modified; for example, MLL-EEN, together with CBP (CREB-binding protein) and PRMT1 (protein arginine $\mathrm{N}$-methyltransferase 1), methylate H3R4 [111]. Another interesting shift in the epigenetic activity is the direct translocation of KMT2A to CBP or P300 responsible for the histone acetyltransferase activity of the fusion proteins [112-114]. In general, either a new protumorigenic epigenetic activity can be linked to altered interacting partners of MLL-FPs such as DOT1L, which are not present in wild-type (wt) KMT2A H3K4 methyltransferase COMPASS-like complexes, or a part of KMT2A is directly fused with a protein bearing a different modifying activity, such as CBP. A reverse fusion was also demonstrated as possible-namely, AF4-MLL—which resulted in a protein product having the capacity to induce acute lymphoblastic leukemia (ALL) by promoting transcription elongation in mice or murine hematopoietic progenitor/stem cells through interactions with DOT1L, $\mathrm{P}-\mathrm{TEFb}$ (Pol II-positive transcription elongation factor), and other core subunits of the MLL-FP complexes. This positive regulation of RNAP II by P-TEFb allows for productive transcription and the synthesis of proteins involved in cell transformation [115-117]. It has been shown that wt KMT2A is essential for leukemogenesis and helps maintain the cells that were transformed due to the action of MLL-AF9. An important role in this process is played by Menin, which associates with both wt KMT2A and MLL-AF9 to recruit them to HOX genes for activating their transcription. Apart from catalyzing the methylation of H3K4, wt KMT2A reinforces MLL-AF9-dependent H3K79 methylation at the target genes such as HOX genes, as it was demonstrated that H3K79me was reduced at this locus in the wt KMT2A knockdown cells. The wt allele also upregulates pro-proliferating cell cycle genes such as CCNA2. It can be concluded that both alleles, the wt and rearranged ones, are crucial in the oncogenic transformation of blood cells [118]. It is of note that the capacity of MLL-FPs to transform hematopoietic stem cells is dose-dependent. These chimeric proteins facilitate self-renewal, enhance the expression of antiapoptotic genes, and induce the synthesis of drug efflux pumps, all of which are inherent properties of stem cells $[97,119]$. Such leukemia stem cell-specific transcription programs are achieved by the MLL-FP complexes that directly target genes such as HOXA9, HOXA10, and MEIS1 [120,121]. The composition of the wt MLL and MLL-FP complexes is presented in Figure 5c,d. 


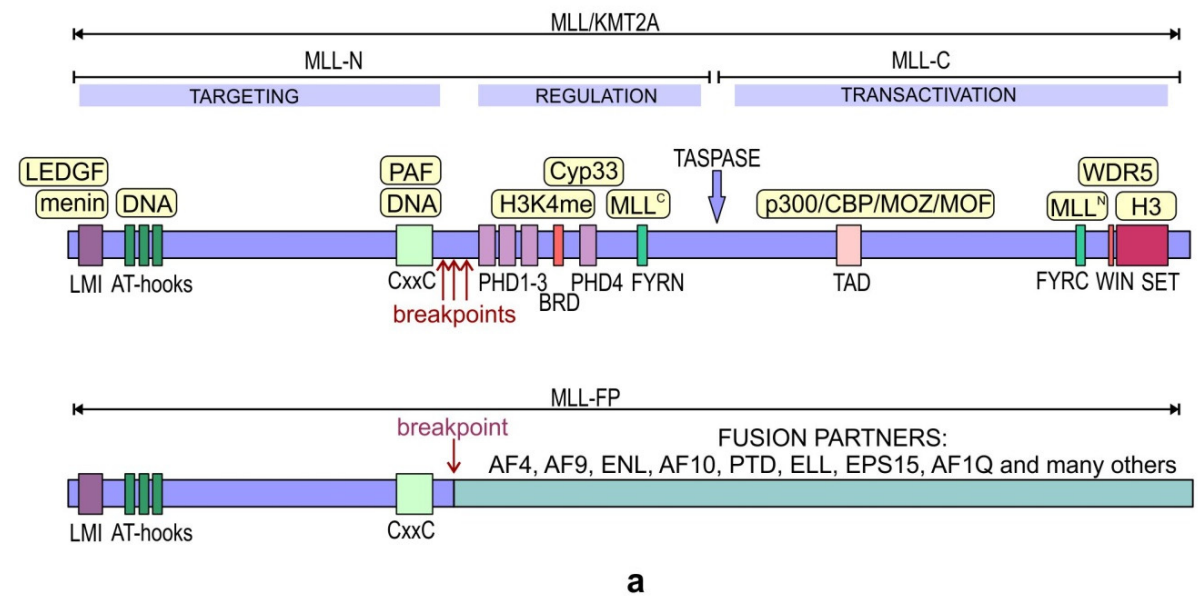

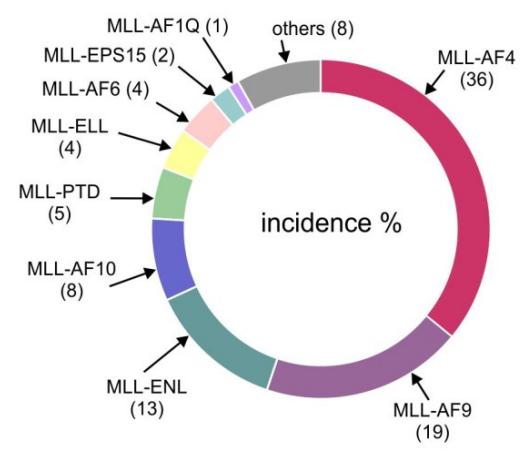

b
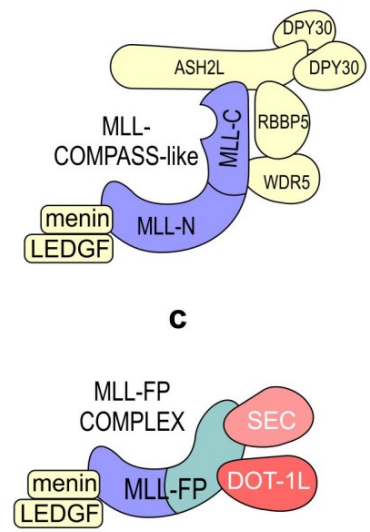

d

Figure 5. Wild-type KMT2A (MLL) and diverse KMT2A-fusion proteins (MLL-FPs). (a) Schematic representation of the wild-type (wt) KMT2A structure. Each domain is labeled in black capital letters, while interacting proteins are marked in rounded yellow-shaded rectangles. A cleavage site recognized by taspase 1 is annotated with a blue arrow. Three major functional parts of the protein responsible for targeting, regulation, and transactivation are also indicated. The protein product of the MLL/KMT2A gene is composed of 3969 amino acids and contains many domains that are involved in the regulation of gene transcription [122]. These include an AT-hook motif-binding DNA [123], a CXXC domain rich in cysteines [124,125], homeodomain (PHD) finger motifs [126], a bromodomain (BRD) [127], and a potent transcriptional activation domain (TAD) located between the amino acids 2829 and 2883 [128,129]. The KMT2A protein also contains a WIN motif responsible for the interaction with WDR5 and maintaining the H3K4me2 activity of the MLL core complex in vitro [130-132]. At the carboxy-terminal part of the protein, there is a SET domain conferring the histone methyltransferase activity of MLL [133,134]. A natural maturation course of MLL includes its proteolysis into two fragments, MLL-N and MLL-C, which then form a complex in vivo $[135,136]$. Two motifs-namely, FYRC and FYRN—are indispensable for heterodimerization between the terminal fragments of cleaved MLL, which can interact with many other proteins to form multiunit complexes required for transcriptional coactivator activity [134,137]. In MLL-FPs, many N-terminal domains, such as PHD, FYRN, FYRC, and SET, are lost. A detailed description is provided in the main text. (b) The most frequent rearrangements of KMT2A (MLL) in MLL. The data were obtained from Meyer et al. [99]. The three most frequent translocations of MLL are with AF4, AF9, and ENL. (c) Composition of the wt MLL COMPASS-like complex containing MLL-N and MLL-C. Core subunits (DPY30, ASH2L, WDR5, and RBBP5); Menin; and LEDGF are shown. (d) Composition of an MLL-FP complex. It contains MLL-FP, DOT1L, SEC, Menin, and LEDGF-the last two proteins are present in both wt and rearranged complexes. 
The majority of MLL cases are very young patients under one year of age suffering from ALLs, while a few are young- to middle-aged adults developing acute myeloid leukemias (AMLs). There is also a third group of patients who are much rarer and treated with chemotherapeutic agents, the side effects of which can induce the so-called therapy-related leukemia [138]. One of the drugs targeting the DNA topoisomerase II induces 11q23 translocations and leads to the treatment-related development of AML $[139,140]$. It should be stressed here that most KMT2A translocations have been linked to a poor prognosis in patients with MLLs [141]. The term "mixed-lineage leukemia" reflects an observation that, during chemotherapy, ALL patients may relapse as AML patients and that myeloid/lymphoid phenotypes can be reversed in some cases $[142,143]$. This is supported by the fact that around $5 \%$ of ALLs and $5-10 \%$ of AMLs in adults are due to MLL rearrangements [97,144].

KMT2A gene rearrangements in leukemias have been studied for the longest time [97]. Nevertheless, new fusions are still being found, including the ones very recently described in solid tumors such as sarcomas [145]. Other types of KMT2A mutations have also been reported, which include tandem duplications and gene amplifications, as well as mutations in the coding region, such as missense, nonsense, and frameshift ones [146]. Although these mutations are not really frequent in leukemias, they appear at a higher incidence in numerous solid tumors [147-150]. Most of the KMT2A mutations induce the production of truncated proteins with a lost SET domain activity, while others can affect the N-terminal part of the protein, which is devoid of PHD, CXXC, or the WDR5-interacting domain [146]. In the vast majority of cancers, all the reported KMT2A mutations are heterozygous, which means that at least one wt KMT2A allele is not altered. The loss of one $K M T 2 A$ allele is insufficient to trigger leukemogenesis or induce cell transformation in other tissues, as demonstrated by genetic studies in mice. The same lack of predisposition to cancer development was observed in patients with haploinsufficient germline KMT2A mutations (one allele is mutated, one is not, and the concentration of the gene product is decreased). This indicates that, on the one hand, leukemic transformation can be driven by the GOF KMT2A translocations producing MLL-FPs, while, on the other hand, the development of cancers carrying KMT2A loss-of-function alterations most probably need additional transforming events independent of KMT2A. Whether KMT2A mutations have the potency to drive cell transformation or act only as a permissive background for oncogenesis is a question that remains to be answered [146].

Accumulating data demonstrate that KMT2A can play various roles in the development and maintenance of cancers. As mentioned earlier, wt KMT2A is important to sustain the leukemic state of cells transformed by the actions of some MLL-FPs. The presence of wt KMT2A is also crucial in other types of cancers in which KMT2A is overexpressed. For example, the knockdown of KMT2A in cervical cancer cells (HeLa) using antisense RNA resulted in increased apoptosis. This effect, to a lesser extent, was also observed in other cancer cells but not in nonmalignant ones. This suggests that cancer cells are more sensitive than normal cells to the loss of KMT2A activity, which is required to maintain their oncogenic phenotype. Moreover, it was demonstrated that KMT2A, together with hypoxia-inducible factor $1 \alpha$ (HIF1 $\alpha)$, were overexpressed in tumor regions with reduced oxygen levels. The KMT2A knockdown influenced angiogenesis by reducing the expression of HIF1 $\alpha$ and vascular endothelial growth factor (VEGF) in cervical cancer xenografts. Additionally, it led to the suppression of xenografted tumor growth in vivo. These data suggest that KMT2A acts as an important factor in hypoxia signaling, vasculogenesis, and tumor growth [151]. Another study reported an increased activity of KMT2A and the global distribution of an H3K4me3 mark at promoter sequences in the salivary gland and head and neck squamous cell carcinomas, which were dependent on the high activity of Wnt- $\beta$-catenin signaling [152]. A very interesting recent study shed more light on how crucial the role of KMT2A is in these solid tumors. GOF Wnt $/ \beta$-catenin increased KMT2A activity, leading to high H3K4me3 at the promoters of Axin2, Id2, Tcf7l2, Tiam1, and Ephb3, which are well-established Wnt target genes. By the genetic ablation of KMT2A (CRISPR/Cas9), as well as mutations of the SET domain or the pharmacological inhibition of important protein-protein interactions of the KMT2A complex, it was shown that the H3K4me3 mark was reduced in tumor cells, and the sizes of tumor 
organoids and tumor spheres were greatly diminished [153]. An increased KMT2A expression was also found in solid tumors with GOF mutations of TP53 [154]. In these cancers, p53 mutants bound to and upregulated the genes encoding KMT2A, KMT2D, and acetyltransferase MOZ (KAT6A), resulting in the global enhancement of H3K4 methylation and histone acetylation, as well as upregulation of the KMT2A target genes, including the HOXA gene cluster. The KMT2A knockdown or pharmacological inhibition of KMT2A were sufficient to inhibit tumor progression, which indicates that KMT2A is essential for the cancer phenotype of cells containing GOF p53 mutants and for driving cancer growth.

KMT2B is generally considered to positively regulate cell growth [155], and homozygous KMT2B inactivation in ES cells leads to defects in cell proliferation and apoptotic outcome $[155,156]$. A region harboring the KMT2B gene was shown to be amplified in certain pancreatic cancer cells and was frequently translocated in glioblastomas [157]. Similar to KMT2A, KMT2B haploinsufficiency in mice, whether germline or conditional, did not show any potency to initiate oncogenesis $[155,158,159]$. Moreover, KMT2B carries similar mutations in cancers, which are predominantly missense, nonsense, and frameshift affecting the SET and PHD domains [146]. KMT2B displays higher mutation rates in uterine corpus endometrial carcinoma (UCEC), as demonstrated by the next-generation sequencing approach [160], and in gastric cancer [161] and esophageal sarcomatoid carcinoma [162]. A recent study demonstrated in a young man with NF1-GBM (neurofibromatosis 1-glioblastoma) that somatic mutations in KMT2B leading to protein truncation were early driver events of malignant gliomagenesis, whereas other pan-cancer genes were mutated later, as revealed by whole-genome sequencing of the patient's brain samples analyzed at different times of the disease development [163].

As far as the role of the wt KMT2B in MLL-r leukemia is concerned, it was found to be crucial in the maintenance of MLL-AF9-induced AML cells. Deletion of the wt KMT2B was shown to reduce the overall leukemic cell survival, while the deletion of KMT2A did not affect the MLL-r cells [164]. This observation is in contrast to that described earlier and suggests that the activities of KMT2B and KMT2A could be redundant and substitute each other in some cases of MLL-r leukemia [118].

\subsection{KMT2C (MLL3) and KMT2D (MLL4)}

Unlike KMT2A and KMT2B, KMT2C and KMT2D are known to impede cell proliferation and, oftentimes, are considered as tumor suppressors [36,160,165-168]. Studies based on chromosome aberration mapping established that the genomic regions containing the KMT2C and KMT2D genes were associated with cancer. Deletion of the region containing the KMT2C gene was common in AMLs [169]. Although KMTs were initially studied for their causative role in hematological malignancies resulting from KMT2A rearrangements, we know today that KMT2C and KMT2D are the most frequently mutated among the human cancer genes [160,170-172].

KMT2C and KMT2D share the same types of mutations, mainly nonsense and frameshift alterations in the SET and PHD domains, resulting in a truncated version of the synthesized protein products. Missense alterations in the SET domains of KMT2C and KMT2D have also been reported but very rarely [146]. In addition, a mutation hotspot within the PHD cluster of the KMT2C gene was described, the mutations of which disrupted the interaction of KMT2C with the BAP1 (BRCA1 associated protein-1) tumor suppressor, resulting in poor patient survival in many types of cancer (liver, lung, bladder, and breast). As for KMT2D, the mutations were more evenly distributed across the entire gene [173,174]. Both KMT2D and KMT2C genes were reported to be mutated with an increased frequency in bladder urothelial cell carcinoma (BUCC) [160]. KMT2C is frequently inactivated by deletion in myeloid leukemia [169] and, also, carries somatic mutations in the interdomain regions in glioblastoma multiforme and pancreatic ductal adenocarcinoma (PDAC) [175]. Moreover, the gene is frequently mutated in diffuse-type gastric adenocarcinoma (DGA). The loss of expression of KMT2C in DGA promotes epithelial-mesenchymal transition (EMT) and is linked with worse overall survival [176]. A study showed that KMT2D was mutated in $8.6 \%$ of prostate cancer cases, while the genes of other MLLs had altered copy numbers or had mutations [177]. In another study, KMT2C was several times more frequently mutated ( $7 \%$ of cases) compared to KMT2D $(2.4 \%)$ in breast cancer [178]. 
Furthermore, a range of epigenetic changes, such as restrictive heterochromatin and silencing linked to promoter DNA hypermethylation, in these two genes have been associated with cancer $[179,180]$. Moreover, heterozygous germline inactivating mutations in KMT2D have been linked to several cancers, and decreased germline activity of KMT2D was found in various pediatric cancers. In such cases, epigenetic modifications, along with other driver mutations, would be involved in cell transformation related to misregulated critical signaling pathways controlled by KMT2D [170,181,182]. Heterozygosity of a great number of mutations is common in KMT2C and KMT2D genes. As mentioned earlier, these mutations involve frameshifts, indels (insertions/deletions), and truncation of the SET domain and lead to the inactivation of these proteins. It was concluded that a wt allele of the KMT2C and KMT2D genes is crucial to sustain the viability of cancerous cells, as a total lack of their homozygous inactivating mutations was observed in the malignancies with sequenced genomes [171].

KMT2C is a well-established haploinsufficient tumor-suppressor gene localized on $7 \mathrm{q}$ and is frequently deleted in a hemizygous manner in AML patients $[165,183]$. It was observed that a $\sim 50 \%$ reduction in the gene dosage by KMT2C shRNA in hematopoietic stem and progenitor cells (HSPCs) transplanted to mice triggered the development of leukemia. A similar effect-initiation of leukemia-was demonstrated through the CRISPR/Cas9 suppression of KMT2C in HSPCs in a heterozygous context, where one KMT2C allele was wt and the other was mutated. However, it needs to be noted that the suppression of KMT2C alone does not suffice to induce leukemogenesis, and the cellular background also plays a role, including p53 loss (p53 ${ }^{-/}$HSCPs), which cooperates with KMT2C to impair the differentiation of these cells, leading to a myelodysplastic syndrome (MDS)-like state. Another important feature of 7q deletions in patients with MDS and AML is the loss of other genes that could contribute to tumor suppression. The question of whether these actions of KMT2C and other genes are additive, synergistic, or redundant needs to be answered in future research [165]. A study demonstrated that a loss-of-function mutation in the SET domain within the KMT2C allele in $M L L 3^{\Delta / \Delta}$ mice led to the development of ureter epithelial tumors [36]. Furthermore, the restoration of KMT2C expression reduced the growth of colorectal cancer (CRC) cells and reinforced the genome-wide H3K4me1 mark at the enhancers, which also suggests that inactivated KMT2C could promote CRC development through transcriptional dysregulation [184].

As already mentioned, KMT2C and KMT2D exert their activities at gene enhancers and are generally considered as haploinsufficient tumor suppressors in normal cells. Mutations in KMT2D lead to the misregulation of KMT2D-dependent enhancers, and their effects might be contextand cell type-dependent. Thus, for KMT2D, a more complex cell-specific situation has to be described. KMT2D was found to be involved in many important cellular pathways, such as the p53 signaling pathway and cAMP-mediated signaling, and the promotion of retinoic acid-responsive gene transcription, as demonstrated by the global identification of KMT2D-targeted loci [185]. Moreover, KMT2D interacts directly with p53, thereby promoting the expression of its target genes, which indicates the role of KMT2D in the p53 tumor-suppression pathway. As demonstrated by cell-based assays, the COMPASS-like complex via NCOA6, a multifunctional coactivator, and KMT2C (or its paralog KMT2D) act as p53 coactivators and are required for H3K4 trimethylation and the expression of p53 target genes in response to doxorubicin, a DNA-damaging agent. It was shown that the downregulation of both KMT2C and KMT2D is needed to suppress the doxorubicin-inducible expression of several p53 target genes. These results revealed the redundancy between these two KMT2s [36]. The antitumor activity of KMT2D was also analyzed in a study in which the brain-specific knockout of KMT2D in mice resulted in spontaneous medulloblastoma. The study showed that KMT2D was responsible for establishing super-enhancers and broad H3K4me3 peaks at tumor-suppressor genes, such as Dnmt3a and Bcl6, and activating their expression. The actions of DNMT3 and Bcl6 led to the inhibition of the oncogenic Ras and Notch pathways, respectively [186]. KMT2D is also identified as a lung tumor suppressor. It is frequently mutated in lung cancer, and its lung-specific loss in mice was demonstrated to promote lung cancer by impairing the super-enhancers, including the super-enhancer of the circadian rhythm repressor PER2, which regulates many glycolytic genes [187]. 
On the other hand, a mutated p53 also directly interacts with KMT2D, promoting its recruitment to gene enhancers required for TNF $\alpha$-inducible H3K4me1 and K3K27ac, as observed in colon cancer cells. This interaction was shown to regulate the aberrant activity of the enhancers and, consequently, to activate the expression of tumor-promoting genes in response to chronic TNF $\alpha$ signaling [188]. KMT2D also mediates the ER-dependent transcription regulated by the PI3K pathway in breast cancer [189]. Furthermore, a higher KMT2D expression was associated with a poor prognosis in this cancer type [190]. The downregulation of overexpressed KMT2D in gastric cancer cells resulted in the suppression of the proliferation and induction of apoptosis [191]. In the case of MLL-AF9-induced AML in mice, KMT2D was found to support this MLL-r leukemia, whereas its deletion led to enhanced myelopoiesis and myeloid differentiation and, thus, protected the animals from AML-related death [168].

In recent years, KMT2C and KMT2D methyltransferases have been shown to play an important role in genome stability and DNA repair. These, together with PTIP, a subunit of the KMT2C/KMT2D complexes, were found to increase the instability and induce the degradation of the MRE11-dependent replication fork in BRCA (breast cancer type susceptibility protein)-deficient cells. Following replication stress, the recruitment of the MRE11 nuclease to stalled replication forks was found to be dependent on KMT2C/KMT2D and PTIP and correlated with KMT2C/KMT2D-induced H3K4 methylation at replication forks in BRCA-deficient cells. It has been suggested that the loss of PTIP may confer drug resistance to these cells by restricting the access of MRE11 to stalled replication forks [192]. In addition, KMT2D was found to interact with the helicase RECQL5, which is proposed to counteract the collisions between transcription and replication machinery $[193,194]$. Mutations in KMT2D were shown to cause transcription stress and genome instability [193]. Alterations in KMT2C and KMT2D could also facilitate DNA breaks and chromosomal translocations, possibly in early replicating fragile sites located at early replicating and actively transcribed gene clusters. These regions are particularly prone to replication-transcription collisions and are the source of rearrangements occurring in cancer cells [194]. Furthermore, deficiency of the KMT2C protein in bladder cancer cells was found to be associated with the modified expression of genes involved in the DNA-damage response (DDR) and DNA repair. In particular, these cells have a smaller capacity to repair dsDNA breaks by homologous recombination. Therefore, they are more prone to genomic instability and depend on PARP1/2 for DNA repair, which could be an interesting target for treatments with PARP1/2 inhibitors such as Olaparib, discussed in a later part of this review [195].

\subsection{KMT2F (SET1A) and KMT2G (SET1B)}

Mammalian KMT2F and KMT2G catalyze H3K4me3 across the entire genome and are responsible for bulk H3K4me3 genome-wide [27,51,196]. Similar to other H3K4 methyltransferases, KMT2F and $K M T 2 G$ are mutated in different types of human cancers, whereas missense, nonsense, and frameshift alterations most commonly occur within their SET domain. A special feature of these two KMT2s is their mutations in the N-terminal RRM in certain cancers. However, the frequency of alterations in the RRM is low-3.5\% for KMT2F and 9.4\% for KMT2G [146,197]. The KMT2F complex has been shown to function together with $\beta$-catenin in the regulation of Wnt target genes and control the growth of colorectal cancer (CRC) cells in vitro and in vivo [198]. Furthermore, KMT2F was demonstrated to be upregulated in CRC cells, as was the H3K4me3 global mark in the tissues obtained from CRC patients. The downregulation of this gene turned out to be beneficial, as it inhibited the growth of CRC cells and colony formation [198]. Moreover, KMT2F is commonly duplicated and overexpressed in breast cancer cells $[197,199,200]$, and its ablation leads to the decreased in vitro migration and invasion of these cells. KMT2F induces metastasis by H3K4 methylation at proximal promoters of several different metalloproteases, which are upregulated in breast cancer cells [200]. Furthermore, KMT2F acts as a positive regulator of cell cycle progression through the miRNA network. It has been found to suppress the expression of $B T G 2$, a p53-inducible antiproliferative gene, by inducing several BTG2-targeting microRNAs (miRNAs) [201]. In other studies, this H3K4 methyltransferase was 
demonstrated to promote the growth of liver cancer cells [202] and induce proliferation by regulating several mitosis-related and DDR genes [203]. Interestingly, KMT2F also exerts its oncogenic effect by methylating substrates other than histones. For instance, it was shown to methylate YAP, an effector of the Hippo tumor-suppressor pathway and, thus, regulates the activity of YAP and promotes tumorigenesis [88]. KMT2F has also been demonstrated to methylate HSP70. The KMT2F-catalyzed dimethylation of HSP70 at Lys-561 is specifically increased in cancer cells and regulates the subcellular localization of HPSP70. Methylated HSP70 is predominantly localized in the nucleus, where it interacts with the Aurora B kinase and enhances its activity, thus promoting the proliferation of cancer cells [89]. Taken together, KMT2F plays an oncogenic role, as it is synthesized at higher levels in many cancers compared to normal cells and sustains tumorigenesis.

$K M T 2 G$ was shown to be upregulated in renal clear carcinoma in advanced tumor stages and metastatic cells [204]. Furthermore, an A1054del KMT2G mutant was found to be more potent in inducing proliferation, migration, and invasion, compared to its wt allele in primary hepatic neuroendocrine tumors, by regulating genes such as TP53 [205]. A recent study revealed that a cytoplasmic variant of KMT2G/COMPASS plays an important role in cancer cell survival and the pathogenesis of triple-negative breast cancer (TNBC). KMT2G has been demonstrated to be overexpressed in breast cancer cells and found to be crucial in determining their viability. When KMT2G or its cytoplasmic-interacting protein BOD1 (biorientation of chromosomes in cell division protein 1) were lost from the complex, many genes modulating fatty acid metabolism, such as ADIPOR1 (adiponectin receptor 1), $C O X 7 C, S D C 4$, and $C O Q 7$, were upregulated. These data indicate that ADIPOR1 signaling, inactivated not only in cancer but, also, in obesity, is an important target of the KMT2G complex, suggesting the novel role of SET1B/COMPASS independent of its catalytic activity. Targeting this pathway is described as one of the anticancer strategies in a later part of this review [206].

\section{Roles of the Core Subunits in Oncogenesis}

A growing body of experimental data indicates that not only KMT2 enzymes but, also, the core subunits of the KMT2 complexes are involved in oncogenesis. While KMT2 mutations are present in a diverse set of human cancers, mutations of the core subunits are rarely identified. In contrast, changes in the expression of core subunits have been found to be associated with cancer.

It should be noted that the subunits of the WRAD core complex can interact with many other proteins and are found to be a part of other complexes than KMT2. For example, the WDR5 protein binds to the NSL (nonspecific lethal) complex and may be involved in the acetylation of histone H4 [207], as well as associated with ATAC (Ada2-containing histone acetyltransferase) complexes that acetylate histone H4 at lysine 16 (H4K16) [208]. DPY30 was recently suggested to be a subunit of the NURF complex and associated with it by interacting with the BAP18 subunit [209]. These suggest that the role of the core subunits in cancer may also be related to their other activities beyond KMT2 complexes.

\subsection{WDR5}

In addition to its activating function in KMT2 complexes, WDR5 is involved in their recruitment to chromatin. It interacts with many transcription factors, histone modifications, and chromatin remodeling proteins to recruit KMT2 complexes to genomic loci. Furthermore, WDR5 has been shown to interact with many lncRNAs, such as HOTTIP and NeST, to regulate the lncRNA-mediated trimethylation of $\mathrm{H} 3 \mathrm{~K} 4$, thus controlling gene transcription. More evidence points to the tumor-promoting activity of WDR5. For instance, WDR5 has been found to be overexpressed in a number of cancers, including AML, neuroblastoma, prostate cancer, CRC, and bladder cancer [210-214].

WDR5 was identified to be an important factor in the pathogenesis of AML [211]. It has been found to interact with $\mathrm{C} / \mathrm{EBP} \alpha$-p30 (CCAAT enhancer-binding protein- $\alpha$ ), a short, mutated form of the transcription factor $\mathrm{C} / \mathrm{EBP} \alpha$, the expression of which is characteristic of up to $9 \%$ of $A M L$ cases. Through this interaction, WDR5 directs KMT2A to specific genomic loci regulated by C/EBP $\alpha-p 30$, 
leading to their aberrant regulation and, thus, contributing to the enhanced self-renewal and inhibition of myeloid cell differentiation.

WDR5 also interacts directly with the c-MYC and N-MYC oncoproteins and is an essential cofactor of MYC-driven oncogenesis. The MYC transcription factor binds to DNA in the MYC/MAX dimer form, which recognizes consensus sequences called E-boxes. Recent studies, however, indicate that the association of MYC with chromatin also depends on its interaction with WDR5. Mutations in the MYC protein that disrupt its interaction with WDR5 reduce MYC binding at about $80 \%$ of its target genes and its ability to promote the neoplastic process and formation of iPS cells [61,215]. Amplification of the $\mathrm{N}-\mathrm{MYC}$ oncogene is often observed in cancers of neural origin, such as neuroblastomas, and correlates with aggressive tumor behaviors, as well as poor survival. WDR5 expression is promoted by the N-MYC oncoprotein and is increased in neuroblastoma cells, which is associated with a poor prognosis of patients. The cooperation between WDR5 and MYC in neuroblastoma involves a direct interaction between them in the promoters of N-MYC target genes such as MDM2 and other protumorigenic genes, leading to H3K4 trimethylation and their activation [213]. RNAi-mediated gene silencing of WDR5 or the inhibition of the N-MYC/WDR5 complex formation by a small molecule antagonist of WDR5 inhibits the expression of N-MYC target genes, which suppresses the growth of neuroblastoma cells [213].

Increased levels of the WDR5 protein found in bladder cancer tissues also correlate with advanced tumor stage and poor survival. WDR5 has been shown to promote the proliferation of bladder cancer cells by activating the transcription of cyclin genes and the UHMK1 gene in a manner dependent on histone $\mathrm{H} 3$ lysine 4 trimethylation. Moreover, the elevated levels of this protein were shown to enhance chemoresistance by upregulating the antiapoptotic MCL1 and BIRC3 genes in bladder cancer cells via H3K4me3 [210]. An elevated WDR5 level is also characteristic of CRC cells and is an essential factor promoting CRC metastasis. It has been shown to trigger EMT in response to the PI3K/AKT signaling pathway by directly activating the expression of the ZNF407 gene [214].

It was also found that WDR5 binds to the polycomb Cbx8 protein, in the noncanonical PRC1 complexes, and regulates H3K4me3 on the genes of the Notch network, thus promoting breast cancer [216].

WDR5-MYC interaction also protects the cancer cells from replicative stress and DNA damage, as demonstrated in PDAC [217]. The effect of WDR5 on DDR and cancer sustaining was found in colon cancer studies, which showed that WDR5 depletion sensitized the colon cancer cells to radiation-induced DNA damage [218]. WDR5 also regulates the expression of genes involved in DNA repair, and silencing of its expression leads to an increased response to DNA damage in cells undergoing reprogramming into iPS cells [219]. Furthermore, WDR5/KMT2 complexes have been shown to confer cancer cells with resistance to genotoxic stress by promoting the expression of many genes in the glutathione (GSH) metabolic cascade [220].

The interaction of WDR5 with lncRNAs facilitates the recruitment of WDR5/KMT2A complexes and lncRNA-mediated gene transcription and determines the role of WDR5 as a tumorigenic agent in many cancers. WDR5 has been found to bind many lncRNAs, including HOTTIP, a lncRNA regulating the expression of HOX genes, the upregulation of which is characteristic of various types of human cancers. This interaction has been shown to regulate the properties of pancreatic cancer stem cells by promoting the expression of the HOXA9 locus [221]. In addition, WDR5 physically interacts with the BLACAT2 (bladder cancer-associated transcript 2) lncRNA that is markedly upregulated in bladder cancer with lymph node metastasis. The association of WDR5 with BLACAT2 promotes H3K4 methylation and the upregulation of VEGF-C, a lymphangiogenic growth factor, thereby leading to bladder cancer-associated lymphangiogenesis and lymphatic metastasis [222]. Another lncRNA interacting with WDR5, GCAWKR, promotes the development of gastric cancer by upregulating the expression of the target PTP4A1 gene [223].

The WDR5 protein may also recruit KMT2 complexes to chromatin by recognizing various histone modifications, and this mechanism may contribute to its role in cancer. WDR5 has been shown to be 
overexpressed in prostate cancer and involved in the proliferation of androgen-dependent prostate cancer cells. It was found to bind to H3T11P (PKN1-mediated histone H3 threonine 11 phosphorylation) upon androgen stimulation in androgen-dependent prostate cancer cells to recruit KMT2A complexes and induce the expression of androgen receptor target genes [212]. WDR5 also binds to ACK1-mediated H4Y88ph and directs KMT2D to the promoter of the androgen receptor gene, thereby promoting its expression in castration-resistant prostate cancer [224]. Recent data have demonstrated the recruitment of the WDR5/KMT2A complex to H3R2me1/H3R2me2 marks enriched by $\beta$-catenin signaling in the promoters of the GSH metabolic cascade genes in response to genotoxic stress. This contributes to the restoration of redox homeostasis and confers resistance to genotoxic stress in ovarian cancer cells.

\section{2. $R B B P 5$}

Similar to WDR5, the expression of RBBP5 is also increased in many cancers. A study showed that RBBP5 expression is upregulated in hepatocellular carcinoma and correlates with a poor prognosis of patients [225]. Another study detected an increased level of RBBP5 in glioblastoma, which was significantly associated with the pathology grades [226]. The RBBP5 gene silencing, performed in both studies, inhibited cell proliferation and induced the apoptosis of tumor cells.

A recent study also demonstrated that RBBP5 is essential for the maintenance of glioblastoma cancer stem cells in an inhospitable microenvironment [227]. Glioblastoma cancer stem cells exhibit a lower expression of the innate immune receptor TLR4 (Toll-like receptor 4), which helps them to evade inhibitory innate immune signaling. Since TLR4 inhibits the expression of RBBP5 by activating TBK1 kinase signaling, a lower level of TLR4 in glioblastoma cancer stem cells favors an increased RBBP5 expression, which promotes the expression of pluripotency genes [227].

\section{3. $\mathrm{ASH} 2 \mathrm{~L}$}

ASH2L has been shown to be overexpressed at the protein level in most human tumors and tumor cell lines, and its knockdown inhibited the proliferation of tumor cell lines [228]. An analysis of its oncogenic activities using the rat embryo fibroblast (REF) co-transformation assay showed that ASH2L cooperates efficiently with activated HRAS (Harvey Rat Sarcoma Viral Oncogene Homolog) in REF transformation, which strongly suggests that ASH2L functions as an oncoprotein [228]. Consistent with these results, low levels of ASH2L expression correlated with an increased overall survival in AML patients [229]. Recent studies have also shown that ASH2L may act as a coactivator of ER $\alpha$ and promote the progression of endometrial cancer. ASH2L was found to interact with ER $\alpha$ to regulate a subset of estrogen-induced target genes, such as the PAX2 (paired box 2) transcription factor gene, thereby promoting the proliferation and migration of endometrial cancer cells [230].

\subsection{DPY30}

DPY30, like other core subunits of the KMT2 complexes, has been found to be overexpressed in many cancers. Its increased level was detected in cervical squamous cell carcinoma [231], as well as in Burkitt's lymphoma [232], gastric cancer [233], and ovarian cancer, and correlated with a poor prognosis of patients [234].

Studies on Burkitt's lymphoma have shown that DPY30, like other KMT2 core subunits, is upregulated by the MYC oncoprotein and is significant for the binding of MYC to its target genes; thus, it plays an important role in MYC-driven tumorigenesis. It has been proposed that DPY30, to some extent, regulates MYC recruitment through its role in KMT2 complexes, as well as by interacting with other factors such as BPTF, a subunit of the NURF chromatin remodeling complex [232].

\section{Therapeutic Strategies Targeting the Aberrant Activity of KMT2 Complexes in Cancers}

In recent years, there has been tremendous progress in research aiming to find molecules that can block the activity of H3K4 KMT2 complexes or their downstream pathways, thus abrogating the oncogenic phenotype. Efforts are made to find chemicals that can be used to treat leukemias caused 
by KMT2A rearrangements. These inhibitors can act on proteins recruited to the MLL-FP complexes or wt KMT2A needed to maintain the leukemic state of cells transformed by the actions of MLL-FPs. The histone methyltransferase activity of KMT2A can be blocked by chemicals capable of disrupting KMT2A interactions with the core proteins such as WDR5 [235]. Targeting wt KMT2A activity can be used not only in MLL but, also, in MDS and AML, in which KMT2A amplification or tandem duplication is detected. Among the interactions within the MLL-FP complexes, the main targets are DOT1L and SEC [236-238]. Other subunits, such as Menin or LEDGF, which function in both the MLL and MLL-FP complexes, can also be targeted [236,239]. Furthermore, many other strategies were described, such as the inhibition of KMT2A protein degradation [240] and metabolic pathways [187] or a modified chimeric antigen receptor (CAR) T-cell therapy [241]. Molecular blockers can inhibit the subunits of MLL-FP complexes such as KMT2A-ENL to downregulate MYC expression, which is crucial for MLL-r leukemia. Another approach is the inhibitory targeting of proteins such as BRD4 (bromodomain-containing protein 4) recruited to the regulatory elements of the MYC gene, which can switch off the MYC-dependent leukemia sustainment program [236,242-244].

One inhibitor that has been developed to block the activity of KMT2A is MM-401, a macrocyclic peptidomimetic that antagonizes the interaction of WDR5 and wt KMT2A and, thus, inhibits H3K4 methylation and promotes myeloid differentiation in MLL cells. The action of MM-401 phenocopies KMT2A gene deletion and has no toxicity on normal bone marrow cells or an inhibiting effect toward non-MLL cells [245]. Another interesting example is the chemical compound OICR-9429, which disrupts the interaction between WDR5 with MLL and was demonstrated to reduce the recruitment of KMT2A at the loci occupied by a p30 (also known as C/EBP $\alpha$ ) translational isoform expressed in AML. Through selective inhibition of the proliferation and induction of differentiation, OICR-9429 was found to kill patient-derived AML cells expressing p30 [211]. Another approach using this WDR5 inhibitor involved the p53 pathway. GOF alteration in the TP53 gene led to an increased expression of KMT2A and KMT2D, which, in turn, enhanced genome-wide H3K4 mono- and trimethylation and cancer cell proliferation. Targeting KMT2A complexes with OICR-9429 was shown to inhibit the growth of cancer cells containing TP53 GOF mutations [154]. The list of WDR5 inhibitors disrupting its interaction with KMT2A and N-MYC or compounds inhibiting the arginine-binding cavity of WDR5, also known as the WIN (WDR5-INteraction) site, and displaying antioncogenic activities has been growing in recent years [211,213,217,246-248].

Interesting approaches to block protein-protein interactions within COMPASS-like complexes for inhibiting cancer growth were also proposed for Menin-KMT2A, and several disruptors such as MI-463, MI-503, and M-525 were described $[249,250]$. Menin interacts directly with LEDGF via its integrase-binding domain [21,251]. LEDGF, as a part of the MLL-FP complexes, switches a physiological H3K4me3 to an aberrant cancer-related H3K36me2 [252,253]. It has become a potential therapeutic target due to its essential role in MLL-r leukemia and nonessential involvement in hematopoiesis $[254,255]$. However, up until now, there has been no real success in implementing LEDGF inhibitors, including a cyclic peptide CP65, for the treatment of MLL-r leukemia [256].

DOT1L is recruited to the MLL-FP complexes with fusion proteins such as ENL, AF9, and AF10 [257]. As already explained, DOT1L is responsible for H3K79 methylation in leukemia carried out by MLL-FP complexes [258]. Therefore, research was performed to obtain small molecules with selective inhibitory properties targeting DOT1L, which resulted in the identification of a chemical compound, named EPZ004777, capable of inhibiting DOT1L-dependent H3K79 methylation and downregulating the expression of leukemogenic genes [237]. A similar activity is displayed by another chemical agent, EPZ-5676 (pinometostat) [259]. However, its modest potential as an anticancer drug was not promising, as concluded by a clinical investigation in patients with adult acute leukemia [238]. It is of interest that DOT1L can also be targeted in the leukemias devoid of KMT2A rearrangements [260]—or, even, in the KMT2-unrelated solid tumors-to suppress the proliferation and metastasis of breast cancer cells [261]. 
One crucial transcription factor, the expression of which is regulated by MLL-FP complexes and is essential for sustaining leukemogenesis, is MYC. However, it has a three-dimensional structure that is difficult to be reached by drugs. Therefore, the activity of MLL-FP complex subunits-namely, $\mathrm{BRD} 4, \mathrm{CBP} / \mathrm{p} 300$, and ENL, which interact with the $M Y C$ regulatory elements-is targeted. A chemical compound named I-BET151 displaces BRD4 from chromatin, thereby downregulating BCL2, CDK6, and MYC, and shows a potent antileukemic activity in MLL-r cells and in vivo [236,242,262]. Another approach involved the use of A-485, an inhibitor of the catalytic core of CBP/p300, which turned out to have a very potent anticancer activity against many tumor cells, including MOLM-13 MLL-r leukemic cells [263]. ENL contains a YEATS domain, which is a reader of lysine acetylation (Kac) [264] and was demonstrated to be crucial for the maintenance of MLL-r leukemias. The depletion of ENL by Cas9 in leukemic mice xenotransplanted with MV4-11 or MOLM-13 cells led to the downregulation of key leukemic drivers such as MYC and the prolonged survival of mice $[265,266]$. Later, several compounds were found to inhibit the YEATS domain of AF9 and ENL and downregulate many leukemic driver genes $[267,268]$.

In general, monotherapies are rarely efficient, and the administration of a single agent does not provide the expected therapeutic effect in cancer treatments. Therefore, many researchers have demonstrated that a combination of compounds can improve the antioncogenic outcome. Such synergy was shown in human leukemic cells with SGC0946 and I-BET molecules inhibiting DOT1L and BRD4, respectively [269]. The above-mentioned EPZ004777 and MI-2-2, a second-generation inhibitor of KMT2A-Menin interactions [270,271], are more potent together in downregulating crucial leukemic genes such as MYC, HOXA9, and MEIS1 and reducing the proliferation of MLL-r leukemic cells [272]. Another strategy is the downregulation of $M Y C$ by CBP/p300 inhibition at its bromodomain using I-CBP112, which inhibits the growth of cancer cells in human AML cell lines with MLL-AF9 translocation. The compound was also able to sensitize MOM-13 MLL-r leukemic cells to JQ1, mentioned earlier, and the combination of these two agents resulted in a better antileukemic outcome [273].

Recent studies have shown that stabilizing the wt KMT2A protein in leukemic cells could have therapeutic potential. This would displace the more stable and abundant KMT2A-FPs from chromatin, which, in turn, would abrogate the oncogenic phenotype of these cells. Such an action could be performed by targeting the pathway of UBE2O and interleukin 1 (IL-1) responsible for the degradation of the KMT2A protein. It has been demonstrated that the inhibition of IL-1 receptor-associated kinases (IRAK) has a negative impact on the proliferation of MLL-r leukemic cells both in vitro and in vivo. This new approach of targeting MLL-FP complex degradation pathways could be used for the treatment of MLL-r leukemia, which is aggressive and resistant to other types of therapeutic strategies. It could also be potentially applied in the treatment of other cancer types derived from gene translocation by stabilization of the wt allele [240].

Another interesting approach to treat leukemias and lymphomas is chimeric antigen receptor (CAR) T-cell therapy. In MLL-AF4 B-cell acute lymphoblastic leukemia (ALL or B-ALL), the expression of the PROM1 gene encoding a specific marker (CD133) is regulated by MLL-AF4 and has proven to be a good target for the treatment of MLL-r leukemia [274,275]. The rationale to target CD133 was an acquisition of a CD19-negative myeloid phenotype, allowing for the immune escape of MLL-r B-ALL from CD19 CAR T-cell therapy in some patients $[276,277]$. A recent promising study showed a novel bispecific CD19/CD133 CAR strategy, which can target both CD19 and CD133 [278]. In vitro assays demonstrated its robust cytotoxicity against $\mathrm{CD} 19^{+} \mathrm{CD} 133^{+}$and $\mathrm{CD} 19^{-} \mathrm{CD} 133+\mathrm{B}$ cells, which could help reduce the subsequent lineage switch in MLL-r B-ALL [278]. However, the following concerns were raised. The expression level of PROM1 is similar in both MLL-r B-ALL primary blasts and normal nonlymphoid HSPCs. Therefore, "on-target, off-tumor" toxic effects can be expected, as CD133 can be targeted all the time independently of the CD19 co-expression. Several interesting solutions to overcome these issues were proposed [279]. Thus, CAR T-cell therapy is certainly promising if its limitations are overcome in the upcoming years [241]. 
A great number of molecular strategies were designed for the treatment of KMT2A-related leukemias; however, progress has also been made in other KMT-related cancers in recent years. It is quite impossible to target the activity of tumor suppressors such as KMT2C/D, which are most commonly truncated in various cancers [170]. Instead, histone-modifying enzymes involved in transcriptional repression can be blocked, which helps restore the normal gene expression pattern in KMT2C mutant cells [174]. One such enzyme is EZH2, responsible for H3K27me3, which is a subunit of the polycomb repressive complex 2 (PRC2) [280], which can be blocked by using a GSK126 agent. KMT2C was also demonstrated to participate in DDR, and bladder cancer cells having low KMT2C activity cannot efficiently repair the dsDNA breaks by homologous recombination. Therefore, PARP1/2 inhibitors were proposed as antioncogenic agents for KMT2C-associated cancers [195]. A recent study demonstrated that a KMT2D loss decreased the synthesis of PER2 (Period Circadian Regulator 2), which is involved in the regulation of many glycolytic genes. Thus, pharmacologically contained glycolysis helped repress the tumorigenicity of human lung cancer cells with an inactivated KMT2D gene [187].

While designing inhibitory strategies, much focus was directed to the other roles of H3K4 methyltransferases [281]. For example, KMT2G, regardless of its SET domain, is crucial for suppressing ADIPOR1 cytoplasmic signaling, which induces an oncogenic outcome [206]. As this signaling is very important in TNBC, a previously identified activator of AMPK and PPAR- $\alpha$ (peroxisome proliferator-activated receptor alpha) pathways and agonist of ADIPOR1, named AdipoRon [282], was proposed as a potential agent for the treatment of TNBC [206], as well as other cancers such as pancreatic malignancies, which are KMT2G-unrelated [283].

Although the core subunits of KMT2 complexes such as WDR5, RBBP5, DPY30, and ASH2L are rarely deleted or carry genetic mutations, they are frequently amplified or upregulated in human cancers and act as oncogenes $[218,228,230,232,284]$. Therefore, they could constitute potential targets in molecular therapies for cancer patients. Since WDR5 is only required for the catalytic activity of KMT2A complexes and RBBP5 is an obligatory component regulating all other KMT2 complexes, it could be assumed that RBBP5 antagonists may exert broader inhibitory actions compared to agents targeting WDR5 [146,245,285,286]. DPY30 was found to be upregulated in Burkitt's lymphoma, and its downregulation can have a negative effect on cell transformation dependent on MYC activity. Therefore, DPY30 and H3K4 methylation were suggested as potential epigenetic pathways that could be therapeutically targeted in MYC-dependent cancers [232,284]. DPY30 can be targeted using cell-penetrating peptides (CPPs) derived from ASH2L, which normally binds DPY30 in MLL-FP complexes. The disruption of DPY30-ASH2L interaction by CPPs turned out to be effective in inhibiting the growth of MLL-r leukemic cells and other hematologic cancers that were dependent on MYC activity [287]. The specificity and actions of the chosen inhibitors upon MLL and MLL-FP complexes are depicted in Table 2. 
Table 2. Selected inhibitors targeting the aberrant activity of KMT2 complexes in cancer. Several major targets can be distinguished, including the core subunits (DPY30, RBBP5, ASH2L, and WDR5); LEDGF and Menin present in both wild-type (wt) MLL and MLL-fusion protein (FP) complexes; and "additional" proteins such as DOT1L, BRD4, CBP/p300, and fusion proteins (ENL) present in MLL-FP complexes. Other approaches to inhibit the actions of the mutated KMT2s, such as KMT2C and KMT2D, in cancer involve the use of repression complex blockers or contained glycolysis. More details are provided in the main text. TNBC: triple-negative breast cancer; IRAK: IL-1 receptor-associated kinase; YEATS domain: Yaf9, ENL, AF9, Taf14, Sas5 domain; PARP1/2: Poly(ADP-ribose) polymerase 1/2.

\begin{tabular}{|c|c|c|c|c|}
\hline Mode of Action & Name of Inhibitor & Cellular Outcome & $\begin{array}{l}\text { Targeted Cancer } \\
\text { Cells }\end{array}$ & References \\
\hline $\begin{array}{l}\text { Targeting core } \\
\text { subunits of } \\
\text { COMPASS: }\end{array}$ & $\begin{array}{c}\text { MM-401 } \\
\text { (microcyclic } \\
\text { peptidomimetic) }\end{array}$ & $\begin{array}{c}\text { myeloid } \\
\text { differentiation/phenocopying } \\
\text { KMT2A deletion }\end{array}$ & $\begin{array}{l}\text { MLL-r leukemia } \\
\text { cells in culture }\end{array}$ & {$[245,247]$} \\
\hline \multirow{2}{*}{$\begin{array}{l}\text { Antagonizing the } \\
\text { interaction of } \\
\text { WDR5 and } \\
\text { KMT2A }\end{array}$} & \multirow{2}{*}{$\begin{array}{l}\text { OICR-9429 } \\
\text { (small-molecule } \\
\text { antagonist) }\end{array}$} & $\begin{array}{c}\text { Inhibition of proliferation } \\
\text { and induction of } \\
\text { differentiation }\end{array}$ & $\begin{array}{l}\text { Patient-derived } \\
\text { AML cells } \\
\text { expressing p30 }\end{array}$ & [211] \\
\hline & & $\begin{array}{l}\text { Inhibition of cancer cell } \\
\text { growth }\end{array}$ & $\begin{array}{l}\text { Various tumor cells } \\
\text { with a TP53 gain-of } \\
\text { function (GOF) } \\
\text { mutation }\end{array}$ & [154] \\
\hline Targeting DPY30 & $\begin{array}{l}\text { Cell penetrating } \\
\text { peptides (CPPs) } \\
\text { derived from } \\
\text { ASH2L }\end{array}$ & $\begin{array}{l}\text { Inhibition of cancer cell } \\
\text { growth }\end{array}$ & $\begin{array}{l}\text { MLL-r leukemia } \\
\text { cells/other } \\
\text { MYC-dependent } \\
\text { hematologic } \\
\text { cancers }\end{array}$ & [287] \\
\hline \multirow{3}{*}{$\begin{array}{l}\text { Blocking } \\
\text { interaction of } \\
\text { Menin with } \\
\text { KMT2A }\end{array}$} & $\begin{array}{l}\text { MI-463, MI-503 } \\
\text { (small-molecule } \\
\text { antagonist) }\end{array}$ & $\begin{array}{l}\text { Inhibition of progression of } \\
\text { MLL leukemia in vivo vs. } \\
\text { normal hematopoiesis }\end{array}$ & $\begin{array}{l}\text { MLL-r leukemia } \\
\text { cells/mouse model } \\
\text { of MLL leukemia }\end{array}$ & [249] \\
\hline & $\begin{array}{c}\mathrm{M}-525 \\
\text { (small-molecule } \\
\text { antagonist) }\end{array}$ & $\begin{array}{l}\text { Suppression of } \\
\text { MLL-regulated gene } \\
\text { expression, leukemia cell } \\
\text { growth inhibition }\end{array}$ & $\begin{array}{l}\text { Various cell lines } \\
\text { derived from } \\
\text { MLL-r leukemia } \\
\text { (MV4, MOLM-13, } \\
\text { MOLM-14) }\end{array}$ & [250] \\
\hline & $\begin{array}{c}\text { MI-2-2 } \\
\text { (small-molecule } \\
\text { inhibitor) }\end{array}$ & $\begin{array}{l}\text { Inhibition of cell } \\
\text { proliferation, } \\
\text { downregulation of } \\
\text { differentiation }\end{array}$ & $\begin{array}{l}\text { MLL leukemia cells } \\
\text { (KMT2A-F4 } \\
\text { translocation) }\end{array}$ & {$[270,271]$} \\
\hline $\begin{array}{l}\text { Blocking } \\
\text { interaction of } \\
\text { KMT2A with } \\
\text { LEDGF }\end{array}$ & $\begin{array}{l}\text { CP65 (cyclic } \\
\text { peptide) }\end{array}$ & $\begin{array}{l}\text { Impairment of clonogenic } \\
\text { growth of primary murine } \\
\text { MLL-AF9-expressing } \\
\text { leukemic blasts }\end{array}$ & $\begin{array}{l}\text { MLL-AF9 leukemia } \\
\text { cells }\end{array}$ & [256] \\
\hline \multirow[t]{2}{*}{$\begin{array}{l}\text { Targeting DOT1L } \\
\text { in KMT2A- } \\
\text { rearranged } \\
\text { complexes }\end{array}$} & $\begin{array}{c}\text { EPZ004777 } \\
(\mathrm{S}- \\
\text { adenosylmethionine- } \\
\text { competitive } \\
\text { inhibitor) }\end{array}$ & \multirow[t]{2}{*}{$\begin{array}{c}\text { Downregulation of leukemic } \\
\text { genes, inhibition of H3K79, } \\
\text { inhibition of proliferation }\end{array}$} & \multirow{2}{*}{$\begin{array}{l}\text { Leukemia cells } \\
\text { bearing } \\
\text { MLL-r/extension of } \\
\text { survival in a mouse } \\
\text { MLL xenograft } \\
\text { model or complete } \\
\text { tumor regression }\end{array}$} & {$[237,288]$} \\
\hline & $\begin{array}{c}\text { EPZ-5676 } \\
\text { (pinometostat) }\end{array}$ & & & [259] \\
\hline
\end{tabular}


Table 2. Cont.

\begin{tabular}{|c|c|c|c|c|}
\hline Mode of Action & Name of Inhibitor & Cellular Outcome & $\begin{array}{c}\text { Targeted Cancer } \\
\text { Cells }\end{array}$ & References \\
\hline \multirow{3}{*}{$\begin{array}{l}\text { Dissociation of } \\
\text { interacting } \\
\text { proteins from } \\
\text { MYC regulatory } \\
\text { elements }\end{array}$} & $\begin{array}{c}\text { I-BET } \\
\text { (via BRD4) }\end{array}$ & $\begin{array}{l}\text { Downregulation of } \\
\text { MYC-regulated gene } \\
\text { expression, inhibition of } \\
\text { proliferation }\end{array}$ & $\begin{array}{l}\text { Hematological } \\
\text { cancers (MLL-r } \\
\text { leukemia) }\end{array}$ & $\begin{array}{l}{[242,262,} \\
289]\end{array}$ \\
\hline & $\begin{array}{l}\text { A-485 (via the } \\
\text { catalytic core of } \\
\text { CBP/300) }\end{array}$ & Inhibition of proliferation & $\begin{array}{c}\text { Lineage specific } \\
\text { tumor cells } \\
\text { (hematological and } \\
\text { prostate) }\end{array}$ & [263] \\
\hline & $\begin{array}{l}\text { Inhibitors of } \\
\text { YEATS domain of } \\
\text { AF9 and ENL } \\
(\mathrm{XL}-13 \mathrm{~m})\end{array}$ & $\begin{array}{l}\text { Downregulation of leukemic } \\
\text { gene drivers }\end{array}$ & $\begin{array}{l}\text { MLL-r leukemia } \\
\text { cells }\end{array}$ & {$[267,268]$} \\
\hline $\begin{array}{l}\text { Stabilization of } \\
\text { wt KMT2A }\end{array}$ & IRAK1/4 & $\begin{array}{c}\text { Inhibition of cancer cells } \\
\text { proliferation in vitro/in vivo }\end{array}$ & $\begin{array}{l}\text { MLL-r leukemia } \\
\text { cells }\end{array}$ & {$[240,290]$} \\
\hline $\begin{array}{l}\text { Restoration of } \\
\text { normal gene } \\
\text { expression in } \\
\text { KMT2C } \\
\text { mutant cells }\end{array}$ & $\begin{array}{l}\text { GSK } 126 \text { (via a } \\
\text { subunit of the } \\
\text { polycomb } \\
\text { repressive } \\
\text { complex 2) }\end{array}$ & $\begin{array}{l}\text { Impairment of cell } \\
\text { proliferation, resetting the } \\
\text { epigenetic balance of } \\
\text { polycomb and compass } \\
\text { function }\end{array}$ & $\begin{array}{l}\text { Cells/tumors } \\
\text { bearing mutations } \\
\text { (PHD domain) in } \\
\text { KMT2C }\end{array}$ & [174] \\
\hline $\begin{array}{l}\text { PARP1/2-depdenent } \\
\text { DNA repair }\end{array}$ & $\begin{array}{l}\text { Olaparib (PARP1/2 } \\
\text { inhibitor) }\end{array}$ & $\begin{array}{l}\text { Synthetic lethality of cancer } \\
\text { cells }\end{array}$ & $\begin{array}{l}\text { Cancer cells with } \\
\text { low KMT2C levels } \\
\text { (bladder cancer) }\end{array}$ & [195] \\
\hline $\begin{array}{l}\text { Pharmacologically } \\
\text { contained } \\
\text { glycolysis }\end{array}$ & $\begin{array}{c}\text { Glycolytic } \\
\text { inhibitors } \\
\text { (2-deoxy-D-glucose } \\
\text { (2-DG) }\end{array}$ & $\begin{array}{l}\text { Impediment of tumorigenic } \\
\text { growth }\end{array}$ & $\begin{array}{l}\text { Lung cancer cells } \\
\text { with KMT2D } \\
\text { mutations }\end{array}$ & [187] \\
\hline $\begin{array}{l}\text { Suppression of } \\
\text { ADIPOR } \\
\text { cytoplasmic } \\
\text { signaling }\end{array}$ & $\begin{array}{c}\text { AdipoRon } \\
\text { (ADIPOR agonist) }\end{array}$ & $\begin{array}{l}\text { Induction of cancer cell } \\
\text { death through necroptosis }\end{array}$ & $\begin{array}{l}\text { MIA PaCa-2 tumor } \\
\text { cells/cancer cells } \\
\text { isolated from } \\
\text { patients with } \\
\text { pancreatic } \\
\text { cancer/TNBC cells }\end{array}$ & $\begin{array}{l}{[206,282,} \\
283]\end{array}$ \\
\hline
\end{tabular}

\section{Conclusions and Perspectives}

Recent studies have helped us better understand the structure of the COMPASS complexes and the range of their methylating activities. In addition, the important roles of H3K4 methyltransferases and the core subunits in $\mathrm{H} 3 \mathrm{~K} 4 \mathrm{me} 1 / 2 / 3$ regulation were deciphered to a significant extent. KMT2s are frequently mutated in hematological, as well as a broad range of nonhematological, cancers. In MLL-r leukemia, these alterations are mostly translocations of KMT2A to a number of fusion genes, while, in other cancers, they represent heterozygous nonsense mutations generating a truncated version of KMT2s. Genetic studies performed in mice proved that a loss of the wt allele of KMT2s does not lead to tumorigenesis and that haploinsufficiency alone does not drive cell transformation, and other oncogenic events are also necessary. Cancer genome sequencing has provided us with enormous data; however, it does not answer whether the observed mutations result either in gain- or loss-of-function phenotypes and whether these mutations are recessive or dominant or drivers or passengers. Therefore, additional functional studies are needed to distinguish these cellular outcomes. Mouse models and genome-editing approaches in the study of KMT2-dependent carcinogenesis are expected to greatly improve our knowledge in this field. Another important issue is the function of the KMT2A wt allele in MLL-r leukemias. This also applies to other cancers harboring at least one copy of a given KMT2A 
$w t$ allele while the other is mutated. Understanding the interplay between the translocated/mutated and the wt allele will be crucial for the further development of therapeutic strategies.

Essential components of the KMT2 complexes are the core subunits, which tightly regulate the activity of the COMPASSes. One of them, the WDR5 protein, has drawn a lot of attention, and many different chemicals have been designed to disrupt its function and suppress the leukemogenic phenotype. Moreover, several new targeting strategies have emerged in recent years for the treatment of KMT2-related cancers, and although they still need to be improved, some of them have already been adopted in clinical applications; for example, CAR T-cell therapy is used for the treatment of MLL patients. It can be expected that our expanding knowledge of all KMT2 functions in oncogenesis will provide new, interesting insights that can be helpful in designing even better targeting strategies with great therapeutic potential for cancer patients.

Author Contributions: E.P. and J.D. wrote the draft; E.P., J.D. and K.L. revised the manuscript. All authors have read and agreed to the published version of the manuscript.

Funding: This work was supported by the Polish National Science Centre, grant NN303 813140.

Conflicts of Interest: The authors declare no conflict of interest.

\section{References}

1. Fouad, Y.A.; Aanei, C. Revisiting the hallmarks of cancer. Am. J. Cancer Res. 2017, 7, 1016-1036.

2. Hanahan, D.; Weinberg, R.A. Hallmarks of cancer: The next generation. Cell 2011, 144, 646-674. [CrossRef]

3. Hanahan, D.; Weinberg, R.A. The hallmarks of cancer. Cell 2000, 100, 57-70. [CrossRef]

4. Weinberg, R.A. Coming full circle-from endless complexity to simplicity and back again. Cell 2014, 157, 267-271. [CrossRef]

5. Flavahan, W.A.; Gaskell, E.; Bernstein, B.E. Epigenetic plasticity and the hallmarks of cancer. Science 2017, 357, eaal2380. [CrossRef]

6. Allis, C.D.; Berger, S.L.; Cote, J.; Dent, S.; Jenuwien, T.; Kouzarides, T.; Pillus, L.; Reinberg, D.; Shi, Y.; Shiekhattar, R.; et al. New nomenclature for chromatin-modifying enzymes. Cell 2007, 131, 633-636. [CrossRef]

7. Bulger, M.; Groudine, M. Functional and mechanistic diversity of distal transcription enhancers. Cell 2011, 144, 327-339. [CrossRef]

8. Ruthenburg, A.J.; Allis, C.D.; Wysocka, J. Methylation of lysine 4 on histone H3: Intricacy of writing and reading a single epigenetic mark. Mol. Cell 2007, 25, 15-30. [CrossRef]

9. Zentner, G.E.; Scacheri, P.C. The chromatin fingerprint of gene enhancer elements. J. Biol. Chem. 2012, 287, 30888-30896. [CrossRef]

10. Eissenberg, J.C.; Shilatifard, A. Histone H3 lysine 4 (H3K4) methylation in development and differentiation. Dev. Biol. 2010, 339, 240-249. [CrossRef] [PubMed]

11. Pijnappel, W.W.; Schaft, D.; Roguev, A.; Shevchenko, A.; Tekotte, H.; Wilm, M.; Rigaut, G.; Séraphin, B.; Aasland, R.; Stewart, A.F. The S. cerevisiae SET3 complex includes two histone deacetylases, Hos2 and Hst1, and is a meiotic-specific repressor of the sporulation gene program. Genes Dev. 2001, 15, 2991-3004. [CrossRef]

12. Zhang, X.; Novera, W.; Zhang, Y.; Deng, L.-W. MLL5 (KMT2E): Structure, function, and clinical relevance. Cell. Mol. Life Sci. 2017, 74, 2333-2344. [CrossRef]

13. Dou, Y.; Milne, T.A.; Ruthenburg, A.J.; Lee, S.; Lee, J.W.; Verdine, G.L.; Allis, C.D.; Roeder, R.G. Regulation of MLL1 H3K4 methyltransferase activity by its core components. Nat. Struct. Mol. Biol. 2006, 13, 713-719. [CrossRef]

14. Patel, A.; Dharmarajan, V.; Vought, V.E.; Cosgrove, M.S. On the mechanism of multiple lysine methylation by the human mixed lineage leukemia protein-1 (MLL1) core complex. J. Biol. Chem. 2009, 284, 24242-24256. [CrossRef]

15. Avdic, V.; Zhang, P.; Lanouette, S.; Groulx, A.; Tremblay, V.; Brunzelle, J.; Couture, J.-F. Structural and biochemical insights into MLL1 core complex assembly. Structure 2011, 19, 101-108. [CrossRef]

16. Couture, J.-F.; Skiniotis, G. Assembling a COMPASS. Epigenetics 2013, 8, 349-354. [CrossRef]

17. Southall, S.M.; Wong, P.-S.; Odho, Z.; Roe, S.M.; Wilson, J.R. Structural basis for the requirement of additional factors for MLL1 SET domain activity and recognition of epigenetic marks. Mol. Cell 2009, 33, 181-191. [CrossRef] 
18. Hughes, C.M.; Rozenblatt-Rosen, O.; Milne, T.A.; Copeland, T.D.; Levine, S.S.; Lee, J.C.; Hayes, D.N.; Shanmugam, K.S.; Bhattacharjee, A.; Biondi, C.A.; et al. Menin associates with a trithorax family histone methyltransferase complex and with the hoxc8 locus. Mol. Cell 2004, 13, 587-597. [CrossRef]

19. van Nuland, R.; Smits, A.H.; Pallaki, P.; Jansen, P.W.T.C.; Vermeulen, M.; Timmers, H.T.M. Quantitative dissection and stoichiometry determination of the human SET1/MLL histone methyltransferase complexes. Mol. Cell. Biol. 2013, 33, 2067-2077. [CrossRef]

20. Murai, M.J.; Pollock, J.; He, S.; Miao, H.; Purohit, T.; Yokom, A.; Hess, J.L.; Muntean, A.G.; Grembecka, J.; Cierpicki, T. The same site on the integrase-binding domain of lens epithelium-derived growth factor is a therapeutic target for MLL leukemia and HIV. Blood 2014, 124, 3730-3737. [CrossRef]

21. Yokoyama, A.; Cleary, M.L. Menin critically links MLL proteins with LEDGF on cancer-associated target genes. Cancer Cell 2008, 14, 36-46. [CrossRef]

22. Cho, Y.-W.; Hong, T.; Hong, S.; Guo, H.; Yu, H.; Kim, D.; Guszczynski, T.; Dressler, G.R.; Copeland, T.D.; Kalkum, M.; et al. PTIP associates with MLL3- and MLL4-containing histone H3 lysine 4 methyltransferase complex. J. Biol. Chem. 2007, 282, 20395-20406. [CrossRef]

23. Goo, Y.-H.; Sohn, Y.C.; Kim, D.-H.; Kim, S.-W.; Kang, M.-J.; Jung, D.-J.; Kwak, E.; Barlev, N.A.; Berger, S.L.; Chow, V.T.; et al. Activating Signal Cointegrator 2 Belongs to a Novel Steady-State Complex That Contains a Subset of Trithorax Group Proteins. Mol. Cell. Biol. 2003, 23, 140-149. [CrossRef]

24. Patel, S.R.; Kim, D.; Levitan, I.; Dressler, G.R. The BRCT-domain containing protein PTIP links PAX2 to a histone H3, lysine 4 methyltransferase complex. Dev. Cell 2007, 13, 580-592. [CrossRef]

25. Lee, J.-H.; Tate, C.M.; You, J.-S.; Skalnik, D.G. Identification and characterization of the human Set1B histone H3-Lys4 methyltransferase complex. J. Biol. Chem. 2007, 282, 13419-13428. [CrossRef]

26. Demers, C.; Chaturvedi, C.-P.; Ranish, J.A.; Juban, G.; Lai, P.; Morle, F.; Aebersold, R.; Dilworth, F.J.; Groudine, M.; Brand, M. Activator-mediated Recruitment of the MLL2 Methyltransferase Complex to the $\beta$-globin Locus. Mol. Cell 2007, 27, 573-584. [CrossRef]

27. Deng, C.; Li, Y.; Liang, S.; Cui, K.; Salz, T.; Yang, H.; Tang, Z.; Gallagher, P.G.; Qiu, Y.; Roeder, R.; et al. USF1 and hSET1A mediated epigenetic modifications regulate lineage differentiation and HoxB4 transcription. PLoS Genet. 2013, 9, e1003524. [CrossRef]

28. Aziz, A.; Liu, Q.-C.; Dilworth, F.J. Regulating a master regulator: Establishing tissue-specific gene expression in skeletal muscle. Epigenetics 2010, 5, 691-695. [CrossRef]

29. Fossati, A.; Dolfini, D.; Donati, G.; Mantovani, R. NF-Y Recruits Ash2L to Impart H3K4 Trimethylation on CCAAT Promoters. PLoS ONE 2011, 6. [CrossRef]

30. Kim, A.; Song, S.; Brand, M.; Dean, A. Nucleosome and transcription activator antagonism at human beta-globin locus control region DNase I hypersensitive sites. Nucleic Acids Res. 2007, 35, 5831-5838. [CrossRef]

31. Tan, C.C.; Sindhu, K.V.; Li, S.; Nishio, H.; Stoller, J.Z.; Oishi, K.; Puttreddy, S.; Lee, T.J.; Epstein, J.A.; Walsh, M.J.; et al. Transcription factor Ap2 $\delta$ associates with Ash2l and ALR, a trithorax family histone methyltransferase, to activate Hoxc8 transcription. Proc. Natl. Acad. Sci. USA 2008, 105, 7472-7477. [CrossRef] [PubMed]

32. Ullius, A.; Lüscher-Firzlaff, J.; Costa, I.G.; Walsemann, G.; Forst, A.H.; Gusmao, E.G.; Kapelle, K.; Kleine, H.; Kremmer, E.; Vervoorts, J.; et al. The interaction of MYC with the trithorax protein ASH2L promotes gene transcription by regulating H3K27 modification. Nucleic Acids Res. 2014, 42, 6901-6920. [CrossRef] [PubMed]

33. Ang, Y.-S.; Tsai, S.-Y.; Lee, D.-F.; Monk, J.; Su, J.; Ratnakumar, K.; Ding, J.; Ge, Y.; Darr, H.; Chang, B.; et al. Wdr5 mediates self-renewal and reprogramming via the embryonic stem cell core transcriptional network. Cell 2011, 145, 183-197. [CrossRef] [PubMed]

34. Bertero, A.; Madrigal, P.; Galli, A.; Hubner, N.C.; Moreno, I.; Burks, D.; Brown, S.; Pedersen, R.A.; Gaffney, D.; Mendjan, S.; et al. Activin/nodal signaling and NANOG orchestrate human embryonic stem cell fate decisions by controlling the H3K4me3 chromatin mark. Genes Dev. 2015, 29, 702-717. [CrossRef]

35. Dou, Y.; Milne, T.A.; Tackett, A.J.; Smith, E.R.; Fukuda, A.; Wysocka, J.; Allis, C.D.; Chait, B.T.; Hess, J.L.; Roeder, R.G. Physical association and coordinate function of the H3 K4 methyltransferase MLL1 and the H4 K16 acetyltransferase MOF. Cell 2005, 121, 873-885. [CrossRef]

36. Lee, J.; Kim, D.-H.; Lee, S.; Yang, Q.-H.; Lee, D.K.; Lee, S.-K.; Roeder, R.G.; Lee, J.W. A tumor suppressive coactivator complex of p53 containing ASC-2 and histone H3-lysine-4 methyltransferase MLL3 or its paralogue MLL4. Proc. Natl. Acad. Sci. USA 2009, 106, 8513-8518. [CrossRef] 
37. Tang, Z.; Chen, W.-Y.; Shimada, M.; Nguyen, U.T.T.; Kim, J.; Sun, X.-J.; Sengoku, T.; McGinty, R.K.; Fernandez, J.P.; Muir, T.W.; et al. SET1 and p300 act synergistically, through coupled histone modifications, in transcriptional activation by p53. Cell 2013, 154, 297-310. [CrossRef]

38. Takeda, S.; Chen, D.Y.; Westergard, T.D.; Fisher, J.K.; Rubens, J.A.; Sasagawa, S.; Kan, J.T.; Korsmeyer, S.J.; Cheng, E.H.-Y.; Hsieh, J.J.-D. Proteolysis of MLL family proteins is essential for Taspase1-orchestrated cell cycle progression. Genes Dev. 2006, 20, 2397-2409. [CrossRef]

39. Tyagi, S.; Chabes, A.L.; Wysocka, J.; Herr, W. E2F activation of S phase promoters via association with HCF-1 and the MLL family of histone H3K4 methyltransferases. Mol. Cell 2007, 27, 107-119. [CrossRef]

40. Kawabe, Y.-I.; Wang, Y.X.; McKinnell, I.W.; Bedford, M.T.; Rudnicki, M.A. Carm1 regulates Pax7 transcriptional activity through MLL1/2 recruitment during asymmetric satellite stem cell divisions. Cell Stem Cell 2012, 11, 333-345. [CrossRef]

41. Tschiersch, B.; Hofmann, A.; Krauss, V.; Dorn, R.; Korge, G.; Reuter, G. The protein encoded by the Drosophila position-effect variegation suppressor gene $\mathrm{Su}(\mathrm{var}) 3-9$ combines domains of antagonistic regulators of homeotic gene complexes. EMBO J. 1994, 13, 3822-3831. [CrossRef] [PubMed]

42. Hsieh, J.J.-D.; Cheng, E.H.-Y.; Korsmeyer, S.J. Taspase1: A threonine aspartase required for cleavage of MLL and proper HOX gene expression. Cell 2003, 115, 293-303. [CrossRef]

43. Sanchez, R.; Zhou, M.-M. The PHD finger: A versatile epigenome reader. Trends Biochem. Sci. 2011, 36, 364-372. [CrossRef] [PubMed]

44. Dhar, S.S.; Lee, S.-H.; Kan, P.-Y.; Voigt, P.; Ma, L.; Shi, X.; Reinberg, D.; Lee, M.G. Trans-tail regulation of MLL4-catalyzed H3K4 methylation by H4R3 symmetric dimethylation is mediated by a tandem PHD of MLL4. Genes Dev. 2012, 26, 2749-2762. [CrossRef]

45. Fair, K.; Anderson, M.; Bulanova, E.; Mi, H.; Tropschug, M.; Diaz, M.O. Protein interactions of the MLL PHD fingers modulate MLL target gene regulation in human cells. Mol. Cell. Biol. 2001, 21, 3589-3597. [CrossRef]

46. Park, S.; Osmers, U.; Raman, G.; Schwantes, R.H.; Diaz, M.O.; Bushweller, J.H. The PHD3 Domain of MLL Acts as a CYP33-Regulated Switch between MLL-Mediated Activation and Repression. Biochemistry 2010, 49, 6576-6586. [CrossRef]

47. Wang, J.; Muntean, A.G.; Wu, L.; Hess, J.L. A subset of mixed lineage leukemia proteins has plant homeodomain (PHD)-mediated E3 ligase activity. J. Biol. Chem. 2012, 287, 43410-43416. [CrossRef]

48. Chen, J.; Santillan, D.A.; Koonce, M.; Wei, W.; Luo, R.; Thirman, M.J.; Zeleznik-Le, N.J.; Diaz, M.O. Loss of MLL PHD finger 3 is necessary for MLL-ENL-induced hematopoietic stem cell immortalization. Cancer Res. 2008, 68, 6199-6207. [CrossRef]

49. Muntean, A.G.; Giannola, D.; Udager, A.M.; Hess, J.L. The PHD fingers of MLL block MLL fusion protein-mediated transformation. Blood 2008, 112, 4690-4693. [CrossRef]

50. Ansari, K.I.; Mandal, S.S. Mixed lineage leukemia: Roles in gene expression, hormone signaling and mRNA processing. FEBS J. 2010, 277, 1790-1804. [CrossRef]

51. Fang, L.; Zhang, J.; Zhang, H.; Yang, X.; Jin, X.; Zhang, L.; Skalnik, D.G.; Jin, Y.; Zhang, Y.; Huang, X.; et al. H3K4 Methyltransferase Set1a Is A Key Oct4 Coactivator Essential for Generation of Oct4 Positive Inner Cell Mass. Stem Cells 2016, 34, 565-580. [CrossRef] [PubMed]

52. Sze, C.C.; Ozark, P.A.; Cao, K.; Ugarenko, M.; Das, S.; Wang, L.; Marshall, S.A.; Rendleman, E.J.; Ryan, C.A.; Zha, D.; et al. Coordinated regulation of cellular identity-associated H3K4me3 breadth by the COMPASS family. Sci. Adv. 2020, 6. [CrossRef] [PubMed]

53. Wang, P.; Lin, C.; Smith, E.R.; Guo, H.; Sanderson, B.W.; Wu, M.; Gogol, M.; Alexander, T.; Seidel, C.; Wiedemann, L.M.; et al. Global analysis of H3K4 methylation defines MLL family member targets and points to a role for MLL1-mediated H3K4 methylation in the regulation of transcriptional initiation by RNA polymerase II. Mol. Cell. Biol. 2009, 29, 6074-6085. [CrossRef] [PubMed]

54. Kaikkonen, M.U.; Spann, N.J.; Heinz, S.; Romanoski, C.E.; Allison, K.A.; Stender, J.D.; Chun, H.B.; Tough, D.F.; Prinjha, R.K.; Benner, C.; et al. Remodeling of the enhancer landscape during macrophage activation is coupled to enhancer transcription. Mol. Cell 2013, 51, 310-325. [CrossRef]

55. Heintzman, N.D.; Stuart, R.K.; Hon, G.; Fu, Y.; Ching, C.W.; Hawkins, R.D.; Barrera, L.O.; Van Calcar, S.; $\mathrm{Qu}, \mathrm{C}$; Ching, K.A.; et al. Distinct and predictive chromatin signatures of transcriptional promoters and enhancers in the human genome. Nat. Genet. 2007, 39, 311-318. [CrossRef] 
56. Lee, J.-E.; Wang, C.; Xu, S.; Cho, Y.-W.; Wang, L.; Feng, X.; Baldridge, A.; Sartorelli, V.; Zhuang, L.; Peng, W.; et al. H3K4 mono- and di-methyltransferase MLL4 is required for enhancer activation during cell differentiation. Elife 2013, 2, e01503. [CrossRef]

57. Dreijerink, K.M.A.; Mulder, K.W.; Winkler, G.S.; Höppener, J.W.M.; Lips, C.J.M.; Timmers, H.T.M. Menin links estrogen receptor activation to histone H3K4 trimethylation. Cancer Res. 2006, 66, 4929-4935. [CrossRef]

58. Ananthanarayanan, M.; Li, Y.; Surapureddi, S.; Balasubramaniyan, N.; Ahn, J.; Goldstein, J.A.; Suchy, F.J. Histone H3K4 trimethylation by MLL3 as part of ASCOM complex is critical for NR activation of bile acid transporter genes and is downregulated in cholestasis. Am. J. Physiol. Gastrointest. Liver Physiol. 2011, 300, G771-G781. [CrossRef]

59. Scoville, D.W.; Cyphert, H.A.; Liao, L.; Xu, J.; Reynolds, A.; Guo, S.; Stein, R. MLL3 and MLL4 Methyltransferases Bind to the MAFA and MAFB Transcription Factors to Regulate Islet $\beta$-Cell Function. Diabetes 2015, 64, 3772-3783. [CrossRef]

60. Yang, Z.; Augustin, J.; Hu, J.; Jiang, H. Physical Interactions and Functional Coordination between the Core Subunits of Set1/Mll Complexes and the Reprogramming Factors. PLoS ONE 2015, 10. [CrossRef]

61. Thomas, L.R.; Wang, Q.; Grieb, B.C.; Phan, J.; Foshage, A.M.; Sun, Q.; Olejniczak, E.T.; Clark, T.; Dey, S.; Lorey, S.; et al. Interaction with WDR5 promotes target gene recognition and tumorigenesis by MYC. Mol. Cell 2015, 58, 440-452. [CrossRef] [PubMed]

62. Rampalli, S.; Li, L.; Mak, E.; Ge, K.; Brand, M.; Tapscott, S.J.; Dilworth, F.J. p38 MAPK signaling regulates recruitment of Ash2L-containing methyltransferase complexes to specific genes during differentiation. Nat. Struct. Mol. Biol. 2007, 14, 1150-1156. [CrossRef] [PubMed]

63. Li, X.; Monckton, E.A.; Godbout, R. Ectopic expression of transcription factor AP-2 $\delta$ in developing retina: Effect on PSA-NCAM and axon routing. J. Neurochem. 2014, 129, 72-84. [CrossRef] [PubMed]

64. Lee, J.-H.; Skalnik, D.G. Wdr82 is a C-terminal domain-binding protein that recruits the Setd1A Histone H3-Lys4 methyltransferase complex to transcription start sites of transcribed human genes. Mol. Cell. Biol. 2008, 28, 609-618. [CrossRef]

65. Muntean, A.G.; Tan, J.; Sitwala, K.; Huang, Y.; Bronstein, J.; Connelly, J.A.; Basrur, V.; Elenitoba-Johnson, K.S.J.; Hess, J.L. The PAF complex synergizes with MLL fusion proteins at HOX loci to promote leukemogenesis. Cancer Cell 2010, 17, 609-621. [CrossRef]

66. Tsai, M.-C.; Manor, O.; Wan, Y.; Mosammaparast, N.; Wang, J.K.; Lan, F.; Shi, Y.; Segal, E.; Chang, H.Y. Long noncoding RNA as modular scaffold of histone modification complexes. Science 2010, 329, 689-693. [CrossRef]

67. Deng, C.; Li, Y.; Zhou, L.; Cho, J.; Patel, B.; Terada, N.; Li, Y.; Bungert, J.; Qiu, Y.; Huang, S. HoxBlinc RNA Recruits Set1/MLL Complexes to Activate Hox Gene Expression Patterns and Mesoderm Lineage Development. Cell Rep. 2016, 14, 103-114. [CrossRef]

68. Ayton, P.M.; Chen, E.H.; Cleary, M.L. Binding to nonmethylated CpG DNA is essential for target recognition, transactivation, and myeloid transformation by an MLL oncoprotein. Mol. Cell. Biol. 2004, 24, 10470-10478. [CrossRef]

69. Birke, M.; Schreiner, S.; García-Cuéllar, M.-P.; Mahr, K.; Titgemeyer, F.; Slany, R.K. The MT domain of the proto-oncoprotein MLL binds to CpG-containing DNA and discriminates against methylation. Nucleic Acids Res. 2002, 30, 958-965. [CrossRef]

70. Cierpicki, T.; Risner, L.E.; Grembecka, J.; Lukasik, S.M.; Popovic, R.; Omonkowska, M.; Shultis, D.D.; Zeleznik-Le, N.J.; Bushweller, J.H. Structure of the MLL CXXC domain-DNA complex and its functional role in MLL-AF9 leukemia. Nat. Struct. Mol. Biol. 2010, 17, 62-68. [CrossRef]

71. Hu, D.; Gao, X.; Cao, K.; Morgan, M.A.; Mas, G.; Smith, E.R.; Volk, A.G.; Bartom, E.T.; Crispino, J.D.; Di Croce, L.; et al. Not All H3K4 Methylations Are Created Equal: Mll2/COMPASS Dependency in Primordial Germ Cell Specification. Mol. Cell 2017, 65, 460-475.e6. [CrossRef] [PubMed]

72. Long, H.K.; Blackledge, N.P.; Klose, R.J. ZF-CxxC domain-containing proteins, CpG islands and the chromatin connection. Biochem. Soc. Trans. 2013, 41,727-740. [CrossRef] [PubMed]

73. Xu, C.; Bian, C.; Lam, R.; Dong, A.; Min, J. The structural basis for selective binding of non-methylated CpG islands by the CFP1 CXXC domain. Nat. Commun. 2011, 2, 227. [CrossRef] [PubMed]

74. Aravind, L.; Landsman, D. AT-hook motifs identified in a wide variety of DNA-binding proteins. Nucleic Acids Res. 1998, 26, 4413-4421. [CrossRef] 
75. Slany, R.K.; Lavau, C.; Cleary, M.L. The oncogenic capacity of HRX-ENL requires the transcriptional transactivation activity of ENL and the DNA binding motifs of HRX. Mol. Cell. Biol. 1998, 18, 122-129. [CrossRef] [PubMed]

76. Kim, J.; Daniel, J.; Espejo, A.; Lake, A.; Krishna, M.; Xia, L.; Zhang, Y.; Bedford, M.T. Tudor, MBT and chromo domains gauge the degree of lysine methylation. EMBO Rep. 2006, 7, 397-403. [CrossRef] [PubMed]

77. Musselman, C.A.; Khorasanizadeh, S.; Kutateladze, T.G. Towards understanding methyllysine readout. Biochim. Et Biophys. Acta 2014, 1839, 686-693. [CrossRef]

78. Musselman, C.A.; Lalonde, M.-E.; Côté, J.; Kutateladze, T.G. Perceiving the epigenetic landscape through histone readers. Nat. Struct. Mol. Biol. 2012, 19, 1218-1227. [CrossRef]

79. van Ingen, H.; van Schaik, F.M.A.; Wienk, H.; Ballering, J.; Rehmann, H.; Dechesne, A.C.; Kruijzer, J.A.W.; Liskamp, R.M.J.; Timmers, H.T.M.; Boelens, R. Structural insight into the recognition of the H3K4me3 mark by the TFIID subunit TAF3. Structure 2008, 16, 1245-1256. [CrossRef]

80. Vermeulen, M.; Mulder, K.W.; Denissov, S.; Pijnappel, W.W.M.P.; van Schaik, F.M.A.; Varier, R.A.; Baltissen, M.P.A.; Stunnenberg, H.G.; Mann, M.; Timmers, H.T.M. Selective anchoring of TFIID to nucleosomes by trimethylation of histone H3 lysine 4. Cell 2007, 131, 58-69. [CrossRef]

81. Li, H.; Ilin, S.; Wang, W.; Duncan, E.M.; Wysocka, J.; Allis, C.D.; Patel, D.J. Molecular basis for site-specific read-out of histone H3K4me3 by the BPTF PHD finger of NURF. Nature 2006, 442, 91-95. [CrossRef] [PubMed]

82. Wysocka, J.; Swigut, T.; Xiao, H.; Milne, T.A.; Kwon, S.Y.; Landry, J.; Kauer, M.; Tackett, A.J.; Chait, B.T.; Badenhorst, P.; et al. A PHD finger of NURF couples histone H3 lysine 4 trimethylation with chromatin remodelling. Nature 2006, 442, 86-90. [CrossRef]

83. Kim, S.; Natesan, S.; Cornilescu, G.; Carlson, S.; Tonelli, M.; McClurg, U.L.; Binda, O.; Robson, C.N.; Markley, J.L.; Balaz, S.; et al. Mechanism of Histone H3K4me3 Recognition by the Plant Homeodomain of Inhibitor of Growth 3. J. Biol. Chem. 2016, 291, 18326-18341. [CrossRef]

84. Peña, P.V.; Davrazou, F.; Shi, X.; Walter, K.L.; Verkhusha, V.V.; Gozani, O.; Zhao, R.; Kutateladze, T.G. Molecular mechanism of histone H3K4me3 recognition by plant homeodomain of ING2. Nature 2006, 442, 100-103. [CrossRef] [PubMed]

85. Shi, X.; Hong, T.; Walter, K.L.; Ewalt, M.; Michishita, E.; Hung, T.; Carney, D.; Peña, P.; Lan, F.; Kaadige, M.R.; et al. ING2 PHD domain links histone H3 lysine 4 methylation to active gene repression. Nature 2006, 442, 96-99. [CrossRef] [PubMed]

86. Chung, H.-R.; Xu, C.; Fuchs, A.; Mund, A.; Lange, M.; Staege, H.; Schubert, T.; Bian, C.; Dunkel, I.; Eberharter, A.; et al. PHF13 is a molecular reader and transcriptional co-regulator of H3K4me2/3. Elife 2016, 5. [CrossRef]

87. Morgan, M.A.J.; Rickels, R.A.; Collings, C.K.; He, X.; Cao, K.; Herz, H.-M.; Cozzolino, K.A.; Abshiru, N.A.; Marshall, S.A.; Rendleman, E.J.; et al. A cryptic Tudor domain links BRWD2/PHIP to COMPASS-mediated histone H3K4 methylation. Genes Dev. 2017, 31, 2003-2014. [CrossRef]

88. Fang, L.; Teng, H.; Wang, Y.; Liao, G.; Weng, L.; Li, Y.; Wang, X.; Jin, J.; Jiao, C.; Chen, L.; et al. SET1A-Mediated Mono-Methylation at K342 Regulates YAP Activation by Blocking Its Nuclear Export and Promotes Tumorigenesis. Cancer Cell 2018, 34, 103-118.e9. [CrossRef]

89. Cho, H.-S.; Shimazu, T.; Toyokawa, G.; Daigo, Y.; Maehara, Y.; Hayami, S.; Ito, A.; Masuda, K.; Ikawa, N.; Field, H.I.; et al. Enhanced HSP70 lysine methylation promotes proliferation of cancer cells through activation of Aurora kinase B. Nat. Commun. 2012, 3, 1072. [CrossRef]

90. Li, Y.; Zhao, L.; Tian, X.; Peng, C.; Gong, F.; Chen, Y. Crystal Structure of MLL2 Complex Guides the Identification of a Methylation Site on P53 Catalyzed by KMT2 Family Methyltransferases. Structure 2020, 28, 1141-1148.e4. [CrossRef]

91. Meyer, C.; Hofmann, J.; Burmeister, T.; Gröger, D.; Park, T.S.; Emerenciano, M.; de Oliveira, M.P.; Renneville, A.; Villarese, P.; Macintyre, E.; et al. The MLL recombinome of acute leukemias in 2013. Leukemia 2013, 27, 2165-2176. [CrossRef] [PubMed]

92. Ziemin-van der Poel, S.; McCabe, N.R.; Gill, H.J.; Espinosa, R.; Patel, Y.; Harden, A.; Rubinelli, P.; Smith, S.D.; LeBeau, M.M.; Rowley, J.D. Identification of a gene, MLL, that spans the breakpoint in 11q23 translocations associated with human leukemias. Proc. Natl. Acad. Sci. USA 1991, 88, 10735-10739. [CrossRef] [PubMed]

93. Gu, Y.; Nakamura, T.; Alder, H.; Prasad, R.; Canaani, O.; Cimino, G.; Croce, C.M.; Canaani, E. The t(4;11) chromosome translocation of human acute leukemias fuses the ALL-1 gene, related to Drosophila trithorax, to the AF-4 gene. Cell 1992, 71, 701-708. [CrossRef] 
94. Marschalek, R. Systematic Classification of Mixed-Lineage Leukemia Fusion Partners Predicts Additional Cancer Pathways. Ann. Lab. Med. 2016, 36, 85-100. [CrossRef] [PubMed]

95. Tkachuk, D.C.; Kohler, S.; Cleary, M.L. Involvement of a homolog of Drosophila trithorax by 11q23 chromosomal translocations in acute leukemias. Cell 1992, 71, 691-700. [CrossRef]

96. Richardson, C.; Jasin, M. Frequent chromosomal translocations induced by DNA double-strand breaks. Nature 2000, 405, 697-700. [CrossRef]

97. Krivtsov, A.V.; Armstrong, S.A. MLL translocations, histone modifications and leukaemia stem-cell development. Nat. Rev. Cancer 2007, 7, 823-833. [CrossRef]

98. Roguev, A. The Saccharomyces cerevisiae Set1 complex includes an Ash2 homologue and methylates histone 3 lysine 4. EMBO J. 2001, 20, 7137-7148. [CrossRef]

99. Meyer, C.; Burmeister, T.; Gröger, D.; Tsaur, G.; Fechina, L.; Renneville, A.; Sutton, R.; Venn, N.C.; Emerenciano, M.; Pombo-de-Oliveira, M.S.; et al. The MLL recombinome of acute leukemias in 2017. Leukemia 2018, 32, 273-284. [CrossRef]

100. Aplan, P.D. Chromosomal translocations involving the MLL gene: Molecular mechanisms. DNA Repair 2006, 5, 1265-1272. [CrossRef]

101. Ayton, P.M.; Cleary, M.L. Molecular mechanisms of leukemogenesis mediated by MLL fusion proteins. Oncogene 2001, 20, 5695-5707. [CrossRef]

102. Liu, H.; Cheng, E.H.Y.; Hsieh, J.J.D. MLL fusions: Pathways to leukemia. Cancer Biol. Ther. 2009, 8, $1204-1211$. [CrossRef] [PubMed]

103. Meyer, C.; Schneider, B.; Jakob, S.; Strehl, S.; Attarbaschi, A.; Schnittger, S.; Schoch, C.; Jansen, M.W.J.C.; van Dongen, J.J.M.; den Boer, M.L.; et al. The MLL recombinome of acute leukemias. Leukemia 2006, 20,777-784. [CrossRef]

104. The Groupe Français de Cytogénétique Oncologique; Huret, J.; Dessen, P.; Bernheim, A. An Atlas on Chromosomes in Hematological Malignancies. Example: 11q23 and MLL partners. Leukemia 2001, 15, 987-989. [CrossRef]

105. Collins, C.T.; Hess, J.L. Deregulation of the HOXA9/MEIS1 axis in acute leukemia. Curr. Opin. Hematol. 2016, 23, 354-361. [CrossRef] [PubMed]

106. Okada, Y.; Feng, Q.; Lin, Y.; Jiang, Q.; Li, Y.; Coffield, V.M.; Su, L.; Xu, G.; Zhang, Y. hDOT1L Links Histone Methylation to Leukemogenesis. Cell 2005, 121, 167-178. [CrossRef]

107. Slany, R.K. The molecular mechanics of mixed lineage leukemia. Oncogene 2016, 35, 5215-5223. [CrossRef] [PubMed]

108. Takahashi, S.; Yokoyama, A. The molecular functions of common and atypical MLL fusion protein complexes. Biochim. Et Biophys. Acta (BBA) Gene Regul. Mech. 2020, 1863, 194548. [CrossRef]

109. Vlaming, H.; van Leeuwen, F. The upstreams and downstreams of H3K79 methylation by DOT1L. Chromosoma 2016, 125, 593-605. [CrossRef]

110. Mueller, D.; Bach, C.; Zeisig, D.; Garcia-Cuellar, M.-P.; Monroe, S.; Sreekumar, A.; Zhou, R.; Nesvizhskii, A.; Chinnaiyan, A.; Hess, J.L.; et al. A role for the MLL fusion partner ENL in transcriptional elongation and chromatin modification. Blood 2007, 110, 4445-4454. [CrossRef]

111. Cheung, N.; Chan, L.C.; Thompson, A.; Cleary, M.L.; So, C.W.E. Protein arginine-methyltransferase-dependent oncogenesis. Nat. Cell Biol. 2007, 9, 1208-1215. [CrossRef] [PubMed]

112. Ohnishi, H.; Taki, T.; Yoshino, H.; Takita, J.; Ida, K.; Ishii, M.; Nishida, K.; Hayashi, Y.; Taniwaki, M.; Bessho, F.; et al. A complex $\mathrm{t}(1 ; 22 ; 11)(\mathrm{q} 44 ; \mathrm{q} 13 ; \mathrm{q} 23)$ translocation causing MLL-p300 fusion gene in therapy-related acute myeloid leukemia. Eur. J. Haematol. 2008, 81, 475-480. [CrossRef] [PubMed]

113. Sobulo, O.M.; Borrow, J.; Tomek, R.; Reshmi, S.; Harden, A.; Schlegelberger, B.; Housman, D.; Doggett, N.A.; Rowley, J.D.; Zeleznik-Le, N.J. MLL is fused to CBP, a histone acetyltransferase, in therapy-related acute myeloid leukemia with a $\mathrm{t}(11 ; 16)(\mathrm{q} 23 ; \mathrm{p} 13.3)$. Proc. Natl. Acad. Sci. USA 1997, 94, 8732-8737. [CrossRef] [PubMed]

114. Vo, N.; Goodman, R.H. CREB-binding protein and p300 in transcriptional regulation. J. Biol. Chem. 2001, 276, 13505-13508. [CrossRef]

115. Benedikt, A.; Baltruschat, S.; Scholz, B.; Bursen, A.; Arrey, T.N.; Meyer, B.; Varagnolo, L.; Müller, A.M.; Karas, M.; Dingermann, T.; et al. The leukemogenic AF4-MLL fusion protein causes P-TEFb kinase activation and altered epigenetic signatures. Leukemia 2011, 25, 135-144. [CrossRef] 
116. Bursen, A.; Schwabe, K.; Rüster, B.; Henschler, R.; Ruthardt, M.; Dingermann, T.; Marschalek, R. The AF4.MLL fusion protein is capable of inducing ALL in mice without requirement of MLL·AF4. Blood 2010, 115, 3570-3579. [CrossRef]

117. Price, D.H. P-TEFb, a Cyclin-Dependent Kinase Controlling Elongation by RNA Polymerase II. Mol. Cell. Biol. 2000, 20, 2629-2634. [CrossRef]

118. Thiel, A.T.; Blessington, P.; Zou, T.; Feather, D.; Wu, X.; Yan, J.; Zhang, H.; Liu, Z.; Ernst, P.; Koretzky, G.A.; et al. MLL-AF9-Induced Leukemogenesis Requires Co-Expression of the Wild Type Mll Allele. Cancer Cell 2010, 17, 148-159. [CrossRef]

119. Liedtke, M.; Cleary, M.L. Therapeutic targeting of MLL. Blood 2009, 113, 6061-6068. [CrossRef]

120. Chen, W.; Kumar, A.R.; Hudson, W.A.; Li, Q.; Wu, B.; Staggs, R.A.; Lund, E.A.; Sam, T.N.; Kersey, J.H. Malignant transformation initiated by Mll-AF9: Gene dosage and critical target cells. Cancer Cell 2008, 13, 432-440. [CrossRef]

121. Krivtsov, A.V.; Twomey, D.; Feng, Z.; Stubbs, M.C.; Wang, Y.; Faber, J.; Levine, J.E.; Wang, J.; Hahn, W.C.; Gilliland, D.G.; et al. Transformation from committed progenitor to leukaemia stem cell initiated by MLL-AF9. Nature 2006, 442, 818-822. [CrossRef] [PubMed]

122. Rasio, D.; Schichman, S.A.; Negrini, M.; Canaani, E.; Croce, C.M. Complete exon structure of the ALL1 gene. Cancer Res. 1996, 56, 1766-1769. [PubMed]

123. Reeves, R.; Nissen, M.S. The A.T-DNA-binding domain of mammalian high mobility group I chromosomal proteins. A novel peptide motif for recognizing DNA structure. J. Biol. Chem. 1990, 265, 8573-8582. [PubMed]

124. Bestor, T.H.; Verdine, G.L. DNA methyltransferases. Curr. Opin. Cell Biol. 1994, 6, 380-389. [CrossRef]

125. Shin Voo, K.; Carlone, D.L.; Jacobsen, B.M.; Flodin, A.; Skalnik, D.G. Cloning of a Mammalian Transcriptional Activator That Binds Unmethylated CpG Motifs and Shares a CXXC Domain with DNA Methyltransferase, Human Trithorax, and Methyl-CpG Binding Domain Protein 1. Mol. Cell. Biol. 2000, 20, 2108-2121. [CrossRef] [PubMed]

126. Schindler, U.; Beckmann, H.; Cashmore, A.R. HAT3.1, a novel Arabidopsis homeodomain protein containing a conserved cysteine-rich region. Plant. J. 1993, 4, 137-150. [CrossRef] [PubMed]

127. Tamkun, J.W.; Deuring, R.; Scott, M.P.; Kissinger, M.; Pattatucci, A.M.; Kaufman, T.C.; Kennison, J.A. brahma: A regulator of Drosophila homeotic genes structurally related to the yeast transcriptional activator SNF2/SWI2. Cell 1992, 68, 561-572. [CrossRef]

128. Ernst, P.; Wang, J.; Huang, M.; Goodman, R.H.; Korsmeyer, S.J. MLL and CREB bind cooperatively to the nuclear coactivator CREB-binding protein. Mol. Cell. Biol. 2001, 21, 2249-2258. [CrossRef]

129. Goto, N.K.; Zor, T.; Martinez-Yamout, M.; Dyson, H.J.; Wright, P.E. Cooperativity in transcription factor binding to the coactivator CREB-binding protein (CBP). The mixed lineage leukemia protein (MLL) activation domain binds to an allosteric site on the KIX domain. J. Biol. Chem. 2002, 277, 43168-43174. [CrossRef]

130. Dharmarajan, V.; Lee, J.-H.; Patel, A.; Skalnik, D.G.; Cosgrove, M.S. Structural Basis for WDR5 Interaction (Win) Motif Recognition in Human SET1 Family Histone Methyltransferases. J. Biol. Chem. 2012, 287, 27275-27289. [CrossRef]

131. Patel, A.; Dharmarajan, V.; Cosgrove, M.S. Structure of WDR5 bound to mixed lineage leukemia protein-1 peptide. J. Biol. Chem. 2008, 283, 32158-32161. [CrossRef] [PubMed]

132. Patel, A.; Vought, V.E.; Dharmarajan, V.; Cosgrove, M.S. A conserved arginine-containing motif crucial for the assembly and enzymatic activity of the mixed lineage leukemia protein-1 core complex. J. Biol. Chem. 2008, 283, 32162-32175. [CrossRef]

133. Milne, T.A.; Briggs, S.D.; Brock, H.W.; Martin, M.E.; Gibbs, D.; Allis, C.D.; Hess, J.L. MLL Targets SET Domain Methyltransferase Activity to Hox Gene Promoters. Mol. Cell 2002, 10, 1107-1117. [CrossRef]

134. Nakamura, T.; Mori, T.; Tada, S.; Krajewski, W.; Rozovskaia, T.; Wassell, R.; Dubois, G.; Mazo, A.; Croce, C.M.; Canaani, E. ALL-1 Is a Histone Methyltransferase that Assembles a Supercomplex of Proteins Involved in Transcriptional Regulation. Mol. Cell 2002, 10, 1119-1128. [CrossRef]

135. Hsieh, J.J.-D.; Ernst, P.; Erdjument-Bromage, H.; Tempst, P.; Korsmeyer, S.J. Proteolytic cleavage of MLL generates a complex of $\mathrm{N}$ - and $\mathrm{C}$-terminal fragments that confers protein stability and subnuclear localization. Mol. Cell. Biol. 2003, 23, 186-194. [CrossRef] [PubMed]

136. Yokoyama, A.; Kitabayashi, I.; Ayton, P.M.; Cleary, M.L.; Ohki, M. Leukemia proto-oncoprotein MLL is proteolytically processed into 2 fragments with opposite transcriptional properties. Blood 2002, 100, 3710-3718. [CrossRef] 
137. Yokoyama, A.; Wang, Z.; Wysocka, J.; Sanyal, M.; Aufiero, D.J.; Kitabayashi, I.; Herr, W.; Cleary, M.L. Leukemia proto-oncoprotein MLL forms a SET1-like histone methyltransferase complex with menin to regulate Hox gene expression. Mol. Cell. Biol. 2004, 24, 5639-5649. [CrossRef]

138. Winters, A.C.; Bernt, K.M. MLL-Rearranged Leukemias-An Update on Science and Clinical Approaches. Front. Pediatr. 2017, 5, 4. [CrossRef]

139. Economides, M.P.; McCue, D.; Borthakur, G.; Pemmaraju, N. Topoisomerase II inhibitors in AML: Past, present, and future. Expert Opin. Pharmacother. 2019, 20, 1637-1644. [CrossRef]

140. Super, H.J.; McCabe, N.R.; Thirman, M.J.; Larson, R.A.; Le Beau, M.M.; Pedersen-Bjergaard, J.; Philip, P.; Diaz, M.O.; Rowley, J.D. Rearrangements of the MLL gene in therapy-related acute myeloid leukemia in patients previously treated with agents targeting DNA-topoisomerase II. Blood 1993, 82, 3705-3711. [CrossRef]

141. Britten, O.; Ragusa, D.; Tosi, S.; Kamel, Y.M. MLL-Rearranged Acute Leukemia with t(4;11)(q21;q23)-Current Treatment Options. Is There a Role for CAR-T Cell Therapy? Cells 2019, 8, 1341. [CrossRef] [PubMed]

142. Mirro, J.; Zipf, T.; Pui, C.; Kitchingman, G.; Williams, D.; Melvin, S.; Murphy, S.; Stass, S. Acute mixed lineage leukemia: Clinicopathologic correlations and prognostic significance. Blood 1985, 66, 1115-1123. [CrossRef] [PubMed]

143. Stass, S.; Mirro, J.; Melvin, S.; Pui, C.H.; Murphy, S.B.; Williams, D. Lineage switch in acute leukemia. Blood 1984, 64, 701-706. [CrossRef]

144. Chowdhury, T.; Brady, H.J.M. Insights from clinical studies into the role of the MLL gene in infant and childhood leukemia. Blood Cells Mol. Dis. 2008, 40, 192-199. [CrossRef]

145. Massoth, L.R.; Hung, Y.P.; Nardi, V.; Nielsen, G.P.; Hasserjian, R.P.; Louissaint, A.; Fisch, A.S.; Deshpande, V.; Zukerberg, L.R.; Lennerz, J.K.; et al. Pan-sarcoma genomic analysis of KMT2A rearrangements reveals distinct subtypes defined by YAP1-KMT2A-YAP1 and VIM - KMT2A fusions. Mod. Pathol. 2020, 1-11. [CrossRef] [PubMed]

146. Rao, R.C.; Dou, Y. Hijacked in cancer: The KMT2 (MLL) family of methyltransferases. Nat. Rev. Cancer 2015, 15, 334-346. [CrossRef]

147. Cancer Genome Atlas Research Network; Kandoth, C.; Schultz, N.; Cherniack, A.D.; Akbani, R.; Liu, Y.; Shen, H.; Robertson, A.G.; Pashtan, I.; Shen, R.; et al. Integrated genomic characterization of endometrial carcinoma. Nature 2013, 497, 67-73. [CrossRef]

148. Ding, L.; Getz, G.; Wheeler, D.A.; Mardis, E.R.; McLellan, M.D.; Cibulskis, K.; Sougnez, C.; Greulich, H.; Muzny, D.M.; Morgan, M.B.; et al. Somatic mutations affect key pathways in lung adenocarcinoma. Nature 2008, 455, 1069-1075. [CrossRef]

149. Gui, Y.; Guo, G.; Huang, Y.; Hu, X.; Tang, A.; Gao, S.; Wu, R.; Chen, C.; Li, X.; Zhou, L.; et al. Frequent mutations of chromatin remodeling genes in transitional cell carcinoma of the bladder. Nat. Genet. 2011, 43, 875-878. [CrossRef]

150. Wood, L.D.; Parsons, D.W.; Jones, S.; Lin, J.; Sjöblom, T.; Leary, R.J.; Shen, D.; Boca, S.M.; Barber, T.; Ptak, J.; et al. The genomic landscapes of human breast and colorectal cancers. Science 2007, 318, 1108-1113. [CrossRef]

151. Ansari, K.I.; Kasiri, S.; Mandal, S.S. Histone methylase MLL1 has critical roles in tumor growth and angiogenesis and its knockdown suppresses tumor growth in vivo. Oncogene 2013, 32, 3359-3370. [CrossRef] [PubMed]

152. Wend, P.; Fang, L.; Zhu, Q.; Schipper, J.H.; Loddenkemper, C.; Kosel, F.; Brinkmann, V.; Eckert, K.; Hindersin, S.; Holland, J.D.; et al. Wnt/ $\beta$-catenin signalling induces MLL to create epigenetic changes in salivary gland tumours. EMBO J. 2013, 32, 1977-1989. [CrossRef] [PubMed]

153. Zhu, Q.; Fang, L.; Heuberger, J.; Kranz, A.; Schipper, J.; Scheckenbach, K.; Vidal, R.O.; Sunaga-Franze, D.Y.; Müller, M.; Wulf-Goldenberg, A.; et al. The Wnt-Driven Mll1 Epigenome Regulates Salivary Gland and Head and Neck Cancer. Cell Rep. 2019, 26, 415-428.e5. [CrossRef] [PubMed]

154. Zhu, J.; Sammons, M.A.; Donahue, G.; Dou, Z.; Vedadi, M.; Getlik, M.; Barsyte-Lovejoy, D.; Al-awar, R.; Katona, B.W.; Shilatifard, A.; et al. Gain-of-function p53 mutants co-opt chromatin pathways to drive cancer growth. Nature 2015, 525, 206-211. [CrossRef] [PubMed]

155. Glaser, S.; Schaft, J.; Lubitz, S.; Vintersten, K.; van der Hoeven, F.; Tufteland, K.R.; Aasland, R.; Anastassiadis, K.; Ang, S.-L.; Stewart, A.F. Multiple epigenetic maintenance factors implicated by the loss of Mll2 in mouse development. Development 2006, 133, 1423-1432. [CrossRef] [PubMed] 
156. Lubitz, S.; Glaser, S.; Schaft, J.; Stewart, A.F.; Anastassiadis, K. Increased Apoptosis and Skewed Differentiation in Mouse Embryonic Stem Cells Lacking the Histone Methyltransferase Mll2. Mol. Biol. Cell. 2007, 18, 2356-2366. [CrossRef]

157. Huntsman, D.G.; Chin, S.F.; Muleris, M.; Batley, S.J.; Collins, V.P.; Wiedemann, L.M.; Aparicio, S.; Caldas, C. MLL2, the second human homolog of the Drosophila trithorax gene, maps to $19 q 13.1$ and is amplified in solid tumor cell lines. Oncogene 1999, 18, 7975-7984. [CrossRef]

158. Andreu-Vieyra, C.V.; Chen, R.; Agno, J.E.; Glaser, S.; Anastassiadis, K.; Stewart, A.F.; Matzuk, M.M. MLL2 is required in oocytes for bulk histone 3 lysine 4 trimethylation and transcriptional silencing. PLoS Biol. 2010, 8. [CrossRef]

159. Glaser, S.; Lubitz, S.; Loveland, K.L.; Ohbo, K.; Robb, L.; Schwenk, F.; Seibler, J.; Roellig, D.; Kranz, A.; Anastassiadis, K.; et al. The histone 3 lysine 4 methyltransferase, Mll2, is only required briefly in development and spermatogenesis. Epigenet. Chromatin 2009, 2, 5. [CrossRef]

160. Kandoth, C.; McLellan, M.D.; Vandin, F.; Ye, K.; Niu, B.; Lu, C.; Xie, M.; Zhang, Q.; McMichael, J.F.; Wyczalkowski, M.A.; et al. Mutational landscape and significance across 12 major cancer types. Nature 2013, 502, 333-339. [CrossRef]

161. Ge, S.; Li, B.; Li, Y.; Li, Z.; Liu, Z.; Chen, Z.; Wu, J.; Gao, J.; Shen, L. Genomic alterations in advanced gastric cancer endoscopic biopsy samples using targeted next-generation sequencing. Am. J. Cancer Res. 2017, 7, 1540-1553. [PubMed]

162. Lu, H.; Yang, S.; Zhu, H.; Tong, X.; Xie, F.; Qin, J.; Han, N.; Wu, X.; Fan, Y.; Shao, Y.W.; et al. Targeted next generation sequencing identified clinically actionable mutations in patients with esophageal sarcomatoid carcinoma. BMC Cancer 2018, 18, 251. [CrossRef] [PubMed]

163. Wong, W.H.; Junck, L.; Druley, T.E.; Gutmann, D.H. NF1 glioblastoma clonal profiling reveals KMT2B mutations as potential somatic oncogenic events. Neurology 2019, 93, 1067-1069. [CrossRef] [PubMed]

164. Chen, Y.; Anastassiadis, K.; Kranz, A.; Stewart, A.F.; Arndt, K.; Waskow, C.; Yokoyama, A.; Jones, K.; Neff, T.; Lee, Y.; et al. MLL2, not MLL1, Plays a Major Role in Sustaining MLL-rearranged Acute Myeloid Leukemia. Cancer Cell 2017, 31, 755-770.e6. [CrossRef]

165. Chen, C.; Liu, Y.; Rappaport, A.R.; Kitzing, T.; Schultz, N.; Zhao, Z.; Shroff, A.S.; Dickins, R.A.; Vakoc, C.R.; Bradner, J.E.; et al. MLL3 is a haploinsufficient 7q tumor suppressor in acute myeloid leukemia. Cancer Cell 2014, 25, 652-665. [CrossRef]

166. Froimchuk, E.; Jang, Y.; Ge, K. Histone H3 lysine 4 methyltransferase KMT2D. Gene 2017, 627, 337-342. [CrossRef]

167. Kanda, H.; Nguyen, A.; Chen, L.; Okano, H.; Hariharan, I.K. The Drosophila Ortholog of MLL3 and MLL4, trithorax related, Functions as a Negative Regulator of Tissue Growth. Mol. Cell. Biol. 2013, 33, 1702-1710. [CrossRef]

168. Santos, M.A.; Faryabi, R.B.; Ergen, A.V.; Day, A.M.; Malhowski, A.; Canela, A.; Onozawa, M.; Lee, J.-E.; Callen, E.; Gutierrez-Martinez, P.; et al. DNA-damage-induced differentiation of leukaemic cells as an anti-cancer barrier. Nature 2014, 514, 107-111. [CrossRef]

169. Ruault, M.; Brun, M.E.; Ventura, M.; Roizès, G.; De Sario, A. MLL3, a new human member of the TRX/MLL gene family, maps to 7q36, a chromosome region frequently deleted in myeloid leukaemia. Gene 2002, 284, 73-81. [CrossRef]

170. Fagan, R.J.; Dingwall, A.K. COMPASS Ascending: Emerging clues regarding the roles of MLL3/KMT2C and MLL2/KMT2D proteins in cancer. Cancer Lett. 2019, 458, 56-65. [CrossRef]

171. Ford, D.J.; Dingwall, A.K. The cancer COMPASS: Navigating the functions of MLL complexes in cancer. Cancer Genet. 2015, 208, 178-191. [CrossRef] [PubMed]

172. Lawrence, M.S.; Stojanov, P.; Mermel, C.H.; Robinson, J.T.; Garraway, L.A.; Golub, T.R.; Meyerson, M.; Gabriel, S.B.; Lander, E.S.; Getz, G. Discovery and saturation analysis of cancer genes across 21 tumour types. Nature 2014, 505, 495-501. [CrossRef] [PubMed]

173. Sze, C.C.; Shilatifard, A. MLL3/MLL4/COMPASS Family on Epigenetic Regulation of Enhancer Function and Cancer. Cold Spring Harb. Perspect. Med. 2016, 6. [CrossRef] [PubMed]

174. Wang, L.; Zhao, Z.; Ozark, P.A.; Fantini, D.; Marshall, S.A.; Rendleman, E.J.; Cozzolino, K.A.; Louis, N.; He, X.; Morgan, M.A.; et al. Resetting the epigenetic balance of Polycomb and COMPASS function at enhancers for cancer therapy. Nat. Med. 2018, 24, 758-769. [CrossRef] 
175. Balakrishnan, A.; Bleeker, F.E.; Lamba, S.; Rodolfo, M.; Daniotti, M.; Scarpa, A.; van Tilborg, A.A.; Leenstra, S.; Zanon, C.; Bardelli, A. Novel Somatic and Germline Mutations in Cancer Candidate Genes in Glioblastoma, Melanoma, and Pancreatic Carcinoma. Cancer Res. 2007, 67, 3545-3550. [CrossRef]

176. Cho, S.-J.; Yoon, C.; Lee, J.H.; Chang, K.K.; Lin, J.-X.; Kim, Y.-H.; Kook, M.-C.; Aksoy, B.A.; Park, D.J.; Ashktorab, H.; et al. KMT2C Mutations in Diffuse-Type Gastric Adenocarcinoma Promote Epithelial-to-Mesenchymal Transition. Clin. Cancer Res. 2018, 24, 6556-6569. [CrossRef]

177. Grasso, C.S.; Wu, Y.-M.; Robinson, D.R.; Cao, X.; Dhanasekaran, S.M.; Khan, A.P.; Quist, M.J.; Jing, X.; Lonigro, R.J.; Brenner, J.C.; et al. The mutational landscape of lethal castration-resistant prostate cancer. Nature 2012, 487, 239-243. [CrossRef]

178. Liu, L.; Kimball, S.; Liu, H.; Holowatyj, A.; Yang, Z.-Q. Genetic alterations of histone lysine methyltransferases and their significance in breast cancer. Oncotarget 2015, 6, 2466-2482. [CrossRef]

179. Buck, M.J.; Raaijmakers, L.M.; Ramakrishnan, S.; Wang, D.; Valiyaparambil, S.; Liu, S.; Nowak, N.J.; Pili, R. Alterations in chromatin accessibility and DNA methylation in clear cell renal cell carcinoma. Oncogene 2014, 33, 4961-4965. [CrossRef]

180. Ibragimova, I.; Dulaimi, E.; Slifker, M.J.; Chen, D.D.; Uzzo, R.G.; Cairns, P. A global profile of gene promoter methylation in treatment-naïve urothelial cancer. Epigenetics 2014, 9, 760-773. [CrossRef]

181. Feinberg, A.P.; Koldobskiy, M.A.; Göndör, A. Epigenetic modulators, modifiers and mediators in cancer aetiology and progression. Nat. Rev. Genet. 2016, 17, 284-299. [CrossRef]

182. Feinberg, A.P.; Ohlsson, R.; Henikoff, S. The epigenetic progenitor origin of human cancer. Nat. Rev. Genet. 2006, 7, 21-33. [CrossRef] [PubMed]

183. Jerez, A.; Sugimoto, Y.; Makishima, H.; Verma, A.; Jankowska, A.M.; Przychodzen, B.; Visconte, V.; Tiu, R.V.; O'Keefe, C.L.; Mohamedali, A.M.; et al. Loss of heterozygosity in 7q myeloid disorders: Clinical associations and genomic pathogenesis. Blood 2012, 119, 6109-6117. [CrossRef] [PubMed]

184. Larsson, C.; Cordeddu, L.; Siggens, L.; Pandzic, T.; Kundu, S.; He, L.; Ali, M.A.; Pristovšek, N.; Hartman, K.; Ekwall, K.; et al. Restoration of KMT2C/MLL3 in human colorectal cancer cells reinforces genome-wide H3K4me1 profiles and influences cell growth and gene expression. Clin. Epigenet. 2020, $12,74$. [CrossRef] [PubMed]

185. Guo, C.; Chang, C.-C.; Wortham, M.; Chen, L.H.; Kernagis, D.N.; Qin, X.; Cho, Y.-W.; Chi, J.-T.; Grant, G.A.; McLendon, R.E.; et al. Global identification of MLL2-targeted loci reveals MLL2's role in diverse signaling pathways. Proc. Natl. Acad. Sci. USA 2012, 109, 17603-17608. [CrossRef] [PubMed]

186. Dhar, S.S.; Zhao, D.; Lin, T.; Gu, B.; Pal, K.; Wu, S.J.; Alam, H.; Lv, J.; Yun, K.; Gopalakrishnan, V.; et al. MLL4 Is Required to Maintain Broad H3K4me3 Peaks and Super-Enhancers at Tumor Suppressor Genes. Mol. Cell 2018, 70, 825-841.e6. [CrossRef] [PubMed]

187. Alam, H.; Tang, M.; Maitituoheti, M.; Dhar, S.S.; Kumar, M.; Han, C.Y.; Ambati, C.R.; Amin, S.B.; Gu, B.; Chen, T.-Y.; et al. KMT2D Deficiency Impairs Super-Enhancers to Confer a Glycolytic Vulnerability in Lung Cancer. Cancer Cell 2020, 37, 599-617.e7. [CrossRef]

188. Rahnamoun, H.; Hong, J.; Sun, Z.; Lee, J.; Lu, H.; Lauberth, S.M. Mutant p53 regulates enhancer-associated H3K4 monomethylation through interactions with the methyltransferase MLL4. J. Biol. Chem. 2018, 293, 13234-13246. [CrossRef]

189. Toska, E.; Osmanbeyoglu, H.U.; Castel, P.; Chan, C.; Hendrickson, R.C.; Elkabets, M.; Dickler, M.N.; Scaltriti, M.; Leslie, C.S.; Armstrong, S.A.; et al. PI3K pathway regulates ER-dependent transcription in breast cancer through the epigenetic regulator KMT2D. Science 2017, 355, 1324-1330. [CrossRef]

190. Kim, J.-H.; Sharma, A.; Dhar, S.S.; Lee, S.-H.; Gu, B.; Chan, C.-H.; Lin, H.-K.; Lee, M.G. UTX and MLL4 coordinately regulate transcriptional programs for cell proliferation and invasiveness in breast cancer cells. Cancer Res. 2014, 74, 1705-1717. [CrossRef]

191. Xiong, W.; Deng, Z.; Tang, Y.; Deng, Z.; Li, M. Downregulation of KMT2D suppresses proliferation and induces apoptosis of gastric cancer. Biochem. Biophys. Res. Commun. 2018, 504, 129-136. [CrossRef] [PubMed]

192. Ray Chaudhuri, A.; Callen, E.; Ding, X.; Gogola, E.; Duarte, A.A.; Lee, J.-E.; Wong, N.; Lafarga, V.; Calvo, J.A.; Panzarino, N.J.; et al. Replication fork stability confers chemoresistance in BRCA-deficient cells. Nature 2016, 535, 382-387. [CrossRef] [PubMed]

193. Kantidakis, T.; Saponaro, M.; Mitter, R.; Horswell, S.; Kranz, A.; Boeing, S.; Aygün, O.; Kelly, G.P.; Matthews, N.; Stewart, A.; et al. Mutation of cancer driver MLL2 results in transcription stress and genome instability. Genes Dev. 2016, 30, 408-420. [CrossRef] [PubMed] 
194. Tubbs, A.; Nussenzweig, A. Endogenous DNA Damage as a Source of Genomic Instability in Cancer. Cell 2017, 168, 644-656. [CrossRef] [PubMed]

195. Rampias, T.; Karagiannis, D.; Avgeris, M.; Polyzos, A.; Kokkalis, A.; Kanaki, Z.; Kousidou, E.; Tzetis, M.; Kanavakis, E.; Stravodimos, K.; et al. The lysine-specific methyltransferase KMT2C/MLL3 regulates DNA repair components in cancer. EMBO Rep. 2019, 20. [CrossRef]

196. Piunti, A.; Shilatifard, A. Epigenetic balance of gene expression by Polycomb and COMPASS families. Science 2016, 352. [CrossRef]

197. Cosmic COSMIC -Catalogue of Somatic Mutations in Cancer. Available online: https://cancer.sanger.ac.uk/ cosmic (accessed on 20 October 2020).

198. Salz, T.; Li, G.; Kaye, F.; Zhou, L.; Qiu, Y.; Huang, S. hSETD1A regulates Wnt target genes and controls tumor growth of colorectal cancer cells. Cancer Res. 2014, 74, 775-786. [CrossRef]

199. Kim, S.-S.; Lee, M.-H.; Lee, M.-O. Histone methyltransferases regulate the transcriptional expression of $\mathrm{ER} \alpha$ and the proliferation of tamoxifen-resistant breast cancer cells. Breast Cancer Res. Treat. 2020, 180, 45-54. [CrossRef]

200. Salz, T.; Deng, C.; Pampo, C.; Siemann, D.; Qiu, Y.; Brown, K.; Huang, S. Histone Methyltransferase hSETD1A Is a Novel Regulator of Metastasis in Breast Cancer. Mol. Cancer Res. 2015, 13, 461-469. [CrossRef]

201. Tajima, K.; Yae, T.; Javaid, S.; Tam, O.; Comaills, V.; Morris, R.; Wittner, B.S.; Liu, M.; Engstrom, A.; Takahashi, F.; et al. SETD1A modulates cell cycle progression through a miRNA network that regulates p53 target genes. Nat. Commun. 2015, 6, 8257. [CrossRef]

202. Li, T.; Zheng, Q.; An, J.; Wu, M.; Li, H.; Gui, X.; Pu, H.; Lu, D. SET1A Cooperates With CUDR to Promote Liver Cancer Growth and Hepatocyte-like Stem Cell Malignant Transformation Epigenetically. Mol. Ther. 2016, 24, 261-275. [CrossRef] [PubMed]

203. Tajima, K.; Matsuda, S.; Yae, T.; Drapkin, B.J.; Morris, R.; Boukhali, M.; Niederhoffer, K.; Comaills, V.; Dubash, T.; Nieman, L.; et al. SETD1A protects from senescence through regulation of the mitotic gene expression program. Nat. Commun. 2019, 10, 2854. [CrossRef] [PubMed]

204. Kumar, A.; Kumari, N.; Rai, A.; Singh, S.K.; Kakkar, N.; Prasad, R. Expression and clinical significance of COMPASS family of histone methyltransferases in clear cell renal cell carcinoma. Gene 2018, 674, 31-36. [CrossRef] [PubMed]

205. Choi, Y.J.; Oh, H.R.; Choi, M.R.; Gwak, M.; An, C.H.; Chung, Y.J.; Yoo, N.J.; Lee, S.H. Frameshift mutation of a histone methylation-related gene SETD1B and its regional heterogeneity in gastric and colorectal cancers with high microsatellite instability. Hum. Pathol. 2014, 45, 1674-1681. [CrossRef]

206. Wang, L.; Collings, C.K.; Zhao, Z.; Cozzolino, K.A.; Ma, Q.; Liang, K.; Marshall, S.A.; Sze, C.C.; Hashizume, R.; Savas, J.N.; et al. A cytoplasmic COMPASS is necessary for cell survival and triple-negative breast cancer pathogenesis by regulating metabolism. Genes Dev. 2017, 31, 2056-2066. [CrossRef]

207. Dias, J.; Nguyen, N.V.; Georgiev, P.; Gaub, A.; Brettschneider, J.; Cusack, S.; Kadlec, J.; Akhtar, A. Structural analysis of the KANSL1/WDR5/KANSL2 complex reveals that WDR5 is required for efficient assembly and chromatin targeting of the NSL complex. Genes Dev. 2014, 28, 929-942. [CrossRef]

208. Wang, Y.-L.; Faiola, F.; Xu, M.; Pan, S.; Martinez, E. Human ATAC Is a GCN5/PCAF-containing acetylase complex with a novel NC2-like histone fold module that interacts with the TATA-binding protein. J. Biol. Chem. 2008, 283, 33808-33815. [CrossRef]

209. Tremblay, V.; Zhang, P.; Chaturvedi, C.-P.; Thornton, J.; Brunzelle, J.S.; Skiniotis, G.; Shilatifard, A.; Brand, M.; Couture, J.-F. Molecular Basis for DPY-30 Association to COMPASS-like and NURF Complexes. Structure 2014, 22, 1821-1830. [CrossRef]

210. Chen, X.; Xie, W.; Gu, P.; Cai, Q.; Wang, B.; Xie, Y.; Dong, W.; He, W.; Zhong, G.; Lin, T.; et al. Upregulated WDR5 promotes proliferation, self-renewal and chemoresistance in bladder cancer via mediating H3K4 trimethylation. Sci. Rep. 2015, 5, 8293. [CrossRef]

211. Grebien, F.; Vedadi, M.; Getlik, M.; Giambruno, R.; Grover, A.; Avellino, R.; Skucha, A.; Vittori, S.; Kuznetsova, E.; Smil, D.; et al. Pharmacological targeting of the Wdr5-MLL interaction in C/EBP $\alpha$ N-terminal leukemia. Nat. Chem. Biol. 2015, 11, 571-578. [CrossRef]

212. Kim, J.-Y.; Banerjee, T.; Vinckevicius, A.; Luo, Q.; Parker, J.B.; Baker, M.R.; Radhakrishnan, I.; Wei, J.-J.; Barish, G.D.; Chakravarti, D. A role for WDR5 in integrating threonine 11 phosphorylation to lysine 4 methylation on histone H3 during androgen signaling and in prostate cancer. Mol. Cell 2014, 54, 613-625. [CrossRef] [PubMed] 
213. Sun, Y.; Bell, J.L.; Carter, D.; Gherardi, S.; Poulos, R.C.; Milazzo, G.; Wong, J.W.H.; Al-Awar, R.; Tee, A.E.; Liu, P.Y.; et al. WDR5 Supports an N-Myc Transcriptional Complex That Drives a Protumorigenic Gene Expression Signature in Neuroblastoma. Cancer Res. 2015, 75, 5143-5154. [CrossRef] [PubMed]

214. Tan, X.; Chen, S.; Wu, J.; Lin, J.; Pan, C.; Ying, X.; Pan, Z.; Qiu, L.; Liu, R.; Geng, R.; et al. PI3K/AKT-mediated upregulation of WDR5 promotes colorectal cancer metastasis by directly targeting ZNF407. Cell Death Dis. 2017, 8, e2686. [CrossRef] [PubMed]

215. Thomas, L.R.; Foshage, A.M.; Weissmiller, A.M.; Tansey, W.P. The MYC-WDR5 Nexus and Cancer. Cancer Res. 2015, 75, 4012-4015. [CrossRef] [PubMed]

216. Chung, C.-Y.; Sun, Z.; Mullokandov, G.; Bosch, A.; Qadeer, Z.A.; Cihan, E.; Rapp, Z.; Parsons, R.; Aguirre-Ghiso, J.A.; Farias, E.F.; et al. Cbx8 Acts Non-canonically with Wdr5 to Promote Mammary Tumorigenesis. Cell Rep. 2016, 16, 472-486. [CrossRef]

217. Carugo, A.; Genovese, G.; Seth, S.; Nezi, L.; Rose, J.L.; Bossi, D.; Cicalese, A.; Shah, P.K.; Viale, A.; Pettazzoni, P.F.; et al. In Vivo Functional Platform Targeting Patient-Derived Xenografts Identifies WDR5-Myc Association as a Critical Determinant of Pancreatic Cancer. Cell Rep. 2016, 16, 133-147. [CrossRef]

218. Neilsen, B.K.; Chakraborty, B.; McCall, J.L.; Frodyma, D.E.; Sleightholm, R.L.; Fisher, K.W.; Lewis, R.E. WDR5 supports colon cancer cells by promoting methylation of H3K4 and suppressing DNA damage. BMC Cancer 2018, 18, 673. [CrossRef]

219. Peñalosa-Ruiz, G.; Bousgouni, V.; Gerlach, J.P.; Waarlo, S.; van de Ven, J.V.; Veenstra, T.E.; Silva, J.C.R.; van Heeringen, S.J.; Bakal, C.; Mulder, K.W.; et al. WDR5, BRCA1, and BARD1 Co-regulate the DNA Damage Response and Modulate the Mesenchymal-to-Epithelial Transition during Early Reprogramming. Stem Cell Rep. 2019, 12, 743-756. [CrossRef]

220. Cao, L.; Wu, G.; Zhu, J.; Tan, Z.; Shi, D.; Wu, X.; Tang, M.; Li, Z.; Hu, Y.; Zhang, S.; et al. Genotoxic stress-triggered $\beta$-catenin/JDP2/PRMT5 complex facilitates reestablishing glutathione homeostasis. Nat. Commun. 2019, 10, 3761. [CrossRef]

221. Fu, Z.; Chen, C.; Zhou, Q.; Wang, Y.; Zhao, Y.; Zhao, X.; Li, W.; Zheng, S.; Ye, H.; Wang, L.; et al. LncRNA HOTTIP modulates cancer stem cell properties in human pancreatic cancer by regulating HOXA9. Cancer Lett. 2017, 410, 68-81. [CrossRef]

222. He, W.; Zhong, G.; Jiang, N.; Wang, B.; Fan, X.; Chen, C.; Chen, X.; Huang, J.; Lin, T. Long noncoding RNA BLACAT2 promotes bladder cancer-associated lymphangiogenesis and lymphatic metastasis. J. Clin. Investig. 2018, 128, 861-875. [CrossRef] [PubMed]

223. Ma, M.; Zhang, Y.; Weng, M.; Hu, Y.; Xuan, Y.; Hu, Y.; Lv, K. lncRNA GCAWKR Promotes Gastric Cancer Development by Scaffolding the Chromatin Modification Factors WDR5 and KAT2A. Mol. Ther. 2018, 26, 2658-2668. [CrossRef]

224. Mahajan, K.; Malla, P.; Lawrence, H.R.; Chen, Z.; Sinha, C.K.; Malik, R.; Shukla, S.; Kim, J.; Coppola, D.; Lawrence, N.J.; et al. ACK1 Regulates Histone H4 Tyr88-phosphorylation and AR Gene Expression in Castration Resistant Prostate Cancer. Cancer Cell 2017, 31, 790-803.e8. [CrossRef] [PubMed]

225. Zhou, H.; Bao, J.; Zhu, X.; Dai, G.; Jiang, X.; Jiao, X.; Sheng, H.; Huang, J.; Yu, H. Retinoblastoma Binding Protein 5 Correlates with the Progression in Hepatocellular Carcinoma. BioMed Res. Int. 2018, 2018, 1073432. [CrossRef]

226. Zhao, C.; Chen, W.; Dai, S.; Zhang, X.; Ban, N.; Fan, S.; Bao, Z.; Sun, J.; Shen, C.; Xia, X.; et al. Expression and clinical role of RBQ3 in gliomas. J. Neurol. Sci. 2015, 359, 177-184. [CrossRef]

227. Alvarado, A.G.; Thiagarajan, P.S.; Mulkearns-Hubert, E.E.; Silver, D.J.; Hale, J.S.; Alban, T.J.; Turaga, S.M.; Jarrar, A.; Reizes, O.; Longworth, M.S.; et al. Glioblastoma Cancer Stem Cells Evade Innate Immune Suppression of Self-Renewal through Reduced TLR4 Expression. Cell Stem Cell 2017, 20, 450-461.e4. [CrossRef]

228. Lüscher-Firzlaff, J.; Gawlista, I.; Vervoorts, J.; Kapelle, K.; Braunschweig, T.; Walsemann, G.; Rodgarkia-Schamberger, C.; Schuchlautz, H.; Dreschers, S.; Kremmer, E.; et al. The human trithorax protein hASH2 functions as an oncoprotein. Cancer Res. 2008, 68, 749-758. [CrossRef]

229. Butler, J.S.; Qiu, Y.H.; Zhang, N.; Yoo, S.-Y.; Coombes, K.R.; Dent, S.Y.R.; Kornblau, S.M. Low expression of ASH2L protein correlates with a favorable outcome in acute myeloid leukemia. Leuk. Lymphoma 2017, 58, 1207-1218. [CrossRef] [PubMed]

230. Zeng, K.; Wu, Y.; Wang, C.; Wang, S.; Sun, H.; Zou, R.; Sun, G.; Song, H.; Liu, W.; Sun, N.; et al. ASH2L is involved in promotion of endometrial cancer progression via upregulation of PAX2 transcription. Cancer Sci. 2020, 111, 2062-2077. [CrossRef] [PubMed] 
231. He, F.-X.; Zhang, L.-L.; Jin, P.-F.; Liu, D.-D.; Li, A.-H. DPY30 regulates cervical squamous cell carcinoma by mediating epithelial-mesenchymal transition (EMT). Oncotargets Ther. 2019, 12, 7139-7147. [CrossRef] [PubMed]

232. Yang, Z.; Shah, K.; Busby, T.; Giles, K.; Khodadadi-Jamayran, A.; Li, W.; Jiang, H. Hijacking a key chromatin modulator creates epigenetic vulnerability for MYC-driven cancer. J. Clin. Investig. 2018, 128, 3605-3618. [CrossRef]

233. Lee, Y.J.; Han, M.-E.; Baek, S.-J.; Kim, S.-Y.; Oh, S.-O. Roles of DPY30 in the Proliferation and Motility of Gastric Cancer Cells. PLoS ONE 2015, 10, e0131863. [CrossRef]

234. Zhang, L.; Zhang, S.; Li, A.; Zhang, A.; Zhang, S.; Chen, L. DPY30 is required for the enhanced proliferation, motility and epithelial-mesenchymal transition of epithelial ovarian cancer cells. Int. J. Mol. Med. 2018, 42, 3065-3072. [CrossRef]

235. Lu, K.; Tao, H.; Si, X.; Chen, Q. The Histone H3 Lysine 4 Presenter WDR5 as an Oncogenic Protein and Novel Epigenetic Target in Cancer. Front. Oncol. 2018, 8, 502. [CrossRef]

236. Chan, A.K.N.; Chen, C.-W. Rewiring the Epigenetic Networks in MLL-Rearranged Leukemias: Epigenetic Dysregulation and Pharmacological Interventions. Front. Cell Dev. Biol. 2019, 7. [CrossRef]

237. Daigle, S.R.; Olhava, E.J.; Therkelsen, C.A.; Majer, C.R.; Sneeringer, C.J.; Song, J.; Johnston, L.D.; Scott, M.P.; Smith, J.J.; Xiao, Y.; et al. Selective Killing of Mixed Lineage Leukemia Cells by a Potent Small-Molecule DOT1L Inhibitor. Cancer Cell 2011, 20, 53-65. [CrossRef]

238. Stein, E.M.; Garcia-Manero, G.; Rizzieri, D.A.; Tibes, R.; Berdeja, J.G.; Savona, M.R.; Jongen-Lavrenic, M.; Altman, J.K.; Thomson, B.; Blakemore, S.J.; et al. The DOT1L inhibitor pinometostat reduces H3K79 methylation and has modest clinical activity in adult acute leukemia. Blood 2018, 131, 2661-2669. [CrossRef]

239. Xu, J.; Li, L.; Xiong, J.; denDekker, A.; Ye, A.; Karatas, H.; Liu, L.; Wang, H.; Qin, Z.S.; Wang, S.; et al. MLL1 and MLL1 fusion proteins have distinct functions in regulating leukemic transcription program. Cell Discov. 2016, 2, 1-11. [CrossRef]

240. Liang, K.; Volk, A.G.; Haug, J.S.; Marshall, S.A.; Woodfin, A.R.; Bartom, E.T.; Gilmore, J.M.; Florens, L.; Washburn, M.P.; Sullivan, K.D.; et al. Therapeutic targeting of MLL degradation pathways in MLL-rearranged leukemia. Cell 2017, 168, 59-72.e13. [CrossRef]

241. Rafiq, S.; Hackett, C.S.; Brentjens, R.J. Engineering strategies to overcome the current roadblocks in CAR T cell therapy. Nat. Rev. Clin. Oncol. 2020, 17, 147-167. [CrossRef]

242. Dawson, M.A.; Prinjha, R.K.; Dittmann, A.; Giotopoulos, G.; Bantscheff, M.; Chan, W.-I.; Robson, S.C.; Chung, C.; Hopf, C.; Savitski, M.M.; et al. Inhibition of BET recruitment to chromatin as an effective treatment for MLL-fusion leukaemia. Nature 2011, 478, 529-533. [CrossRef]

243. Jiang, X.; Huang, H.; Li, Z.; Li, Y.; Wang, X.; Gurbuxani, S.; Chen, P.; He, C.; You, D.; Zhang, S.; et al. Blockade of miR-150 maturation by MLL-fusion/MYC/LIN-28 is required for MLL-associated leukemia. Cancer Cell 2012, 22, 524-535. [CrossRef]

244. Zhu, S.; Cheng, X.; Wang, R.; Tan, Y.; Ge, M.; Li, D.; Xu, Q.; Sun, Y.; Zhao, C.; Chen, S.; et al. Restoration of microRNA function impairs MYC-dependent maintenance of MLL leukemia. Leukemia 2020, 34, 2484-2488. [CrossRef]

245. Cao, F.; Townsend, E.C.; Karatas, H.; Xu, J.; Li, L.; Lee, S.; Liu, L.; Chen, Y.; Ouillette, P.; Zhu, J.; et al. Targeting MLL1 H3K4 methyltransferase activity in mixed-lineage leukemia. Mol. Cell 2014, 53, 247-261. [CrossRef]

246. Aho, E.R.; Wang, J.; Gogliotti, R.D.; Howard, G.C.; Phan, J.; Acharya, P.; Macdonald, J.D.; Cheng, K.; Lorey, S.L.; Lu, B.; et al. Displacement of WDR5 from Chromatin by a WIN Site Inhibitor with Picomolar Affinity. Cell Rep. 2019, 26, 2916-2928.e13. [CrossRef]

247. Aho, E.R.; Weissmiller, A.M.; Fesik, S.W.; Tansey, W.P. Targeting WDR5: A WINning Anti-Cancer Strategy? Epigenet. Insights 2019, 12. [CrossRef]

248. Yang, P.; Huang, X.; Lai, C.; Li, L.; Li, T.; Huang, P.; Ouyang, S.; Yan, J.; Cheng, S.; Lei, G.; et al. SET domain containing $1 \mathrm{~B}$ gene is mutated in primary hepatic neuroendocrine tumors. Int. J. Cancer 2019, 145, 2986-2995. [CrossRef]

249. Borkin, D.; He, S.; Miao, H.; Kempinska, K.; Pollock, J.; Chase, J.; Purohit, T.; Malik, B.; Zhao, T.; Wang, J.; et al. Pharmacologic inhibition of the Menin-MLL interaction blocks progression of MLL leukemia in vivo. Cancer Cell 2015, 27, 589-602. [CrossRef] 
250. Xu, S.; Aguilar, A.; Xu, T.; Zheng, K.; Huang, L.; Stuckey, J.; Chinnaswamy, K.; Bernard, D.; Fernández-Salas, E.; Liu, L.; et al. Design of the First-in-Class, Highly Potent Irreversible Inhibitor Targeting the Menin-MLL Protein-Protein Interaction. Angew. Chem. Int. Ed. Engl. 2018, 57, 1601-1605. [CrossRef]

251. Huang, J.; Gurung, B.; Wan, B.; Wan, K.; Hua, X.; Lei, M. The same pocket in menin binds both MLL and JunD, but oppositely regulates transcription. Nature 2012, 482, 542-546. [CrossRef]

252. Eidahl, J.O.; Crowe, B.L.; North, J.A.; McKee, C.J.; Shkriabai, N.; Feng, L.; Plumb, M.; Graham, R.L.; Gorelick, R.J.; Hess, S.; et al. Structural basis for high-affinity binding of LEDGF PWWP to mononucleosomes. Nucleic Acids Res. 2013, 41, 3924-3936. [CrossRef]

253. Zhu, L.; Li, Q.; Wong, S.H.K.; Huang, M.; Klein, B.J.; Shen, J.; Ikenouye, L.; Onishi, M.; Schneidawind, D.; Buechele, C.; et al. ASH1L Links Histone H3 Lysine 36 Dimethylation to MLL Leukemia. Cancer Discov. 2016, 6, 770-783. [CrossRef]

254. El Ashkar, S.; Schwaller, J.; Pieters, T.; Goossens, S.; Demeulemeester, J.; Christ, F.; van Belle, S.; Juge, S.; Boeckx, N.; Engelman, A.; et al. LEDGF/p75 is dispensable for hematopoiesis but essential for MLL-rearranged leukemogenesis. Blood 2018, 131, 95-107. [CrossRef]

255. Milne, T.A. LEDGF: A leukemia-specific target. Blood 2018, 131, 4-5. [CrossRef]

256. Cermáková, K.; Tesina, P.; Demeulemeester, J.; El Ashkar, S.; Méreau, H.; Schwaller, J.; Rezáčová, P.; Veverka, V.; de Rijck, J. Validation and structural characterization of the LEDGF/p75-MLL interface as a new target for the treatment of MLL-dependent leukemia. Cancer Res. 2014, 74, 5139-5151. [CrossRef]

257. Mohan, M.; Herz, H.-M.; Takahashi, Y.-H.; Lin, C.; Lai, K.C.; Zhang, Y.; Washburn, M.P.; Florens, L.; Shilatifard, A. Linking H3K79 trimethylation to Wnt signaling through a novel Dot1-containing complex (DotCom). Genes Dev. 2010, 24, 574-589. [CrossRef]

258. Okada, Y.; Jiang, Q.; Lemieux, M.; Jeannotte, L.; Su, L.; Zhang, Y. Leukaemic transformation by CALM-AF10 involves upregulation of Hoxa5 by hDOT1L. Nat. Cell Biol. 2006, 8, 1017-1024. [CrossRef]

259. Daigle, S.R.; Olhava, E.J.; Therkelsen, C.A.; Basavapathruni, A.; Jin, L.; Boriack-Sjodin, P.A.; Allain, C.J.; Klaus, C.R.; Raimondi, A.; Scott, M.P.; et al. Potent inhibition of DOT1L as treatment of MLL-fusion leukemia. Blood 2013, 122, 1017-1025. [CrossRef]

260. Deshpande, A.J.; Deshpande, A.; Sinha, A.U.; Chen, L.; Chang, J.; Cihan, A.; Fazio, M.; Chen, C.-W.; Zhu, N.; Koche, R.; et al. AF10 regulates progressive H3K79 methylation and HOX gene expression in diverse AML subtypes. Cancer Cell 2014, 26, 896-908. [CrossRef]

261. Zhang, L.; Deng, L.; Chen, F.; Yao, Y.; Wu, B.; Wei, L.; Mo, Q.; Song, Y. Inhibition of histone H3K79 methylation selectively inhibits proliferation, self-renewal and metastatic potential of breast cancer. Oncotarget 2014, 5, 10665-10677. [CrossRef]

262. Junwei, S.; Vakoc, C.R. The mechanisms behind the therapeutic activity of BET bromodomain inhibition. Mol. Cell 2014, 54, 728-736. [CrossRef]

263. Lasko, L.M.; Jakob, C.G.; Edalji, R.P.; Qiu, W.; Montgomery, D.; Digiammarino, E.L.; Hansen, T.M.; Risi, R.M.; Frey, R.; Manaves, V.; et al. Discovery of a selective catalytic p300/CBP inhibitor that targets lineage-specific tumours. Nature 2017, 550, 128-132. [CrossRef]

264. Li, Y.; Wen, H.; Xi, Y.; Tanaka, K.; Wang, H.; Peng, D.; Ren, Y.; Jin, Q.; Dent, S.Y.R.; Li, W.; et al. AF9 YEATS Domain Links Histone Acetylation to DOT1L-Mediated H3K79 Methylation. Cell 2014, 159, 558-571. [CrossRef]

265. Erb, M.A.; Scott, T.G.; Li, B.E.; Xie, H.; Paulk, J.; Seo, H.-S.; Souza, A.; Roberts, J.M.; Dastjerdi, S.; Buckley, D.L.; et al. Transcription control by the ENL YEATS domain in acute leukaemia. Nature 2017, 543, 270-274. [CrossRef]

266. Wan, L.; Wen, H.; Li, Y.; Lyu, J.; Xi, Y.; Hoshii, T.; Joseph, J.K.; Wang, X.; Loh, Y.-H.E.; Erb, M.A.; et al. ENL links histone acetylation to oncogenic gene expression in acute myeloid leukaemia. Nature 2017, 543, 265-269. [CrossRef]

267. Christott, T.; Bennett, J.; Coxon, C.; Monteiro, O.; Giroud, C.; Beke, V.; Felce, S.L.; Gamble, V.; Gileadi, C.; Poda, G.; et al. Discovery of a Selective Inhibitor for the YEATS Domains of ENL/AF9. SLAS Discov. Adv. Life Sci. Drug Discov. 2019, 24, 133-141. [CrossRef]

268. Li, X.; Li, X.-M.; Jiang, Y.; Liu, Z.; Cui, Y.; Fung, K.Y.; van der Beelen, S.H.E.; Tian, G.; Wan, L.; Shi, X.; et al. Structure-guided development of YEATS domain inhibitors by targeting $\pi-\pi-\pi$ stacking. Nat. Chem. Biol. 2018, 14, 1140-1149. [CrossRef] 
269. Gilan, O.; Lam, E.Y.N.; Becher, I.; Lugo, D.; Cannizzaro, E.; Joberty, G.; Ward, A.; Wiese, M.; Fong, C.Y.; Ftouni, S.; et al. Functional interdependence of BRD4 and DOT1L in MLL leukemia. Nat. Struct. Mol. Biol. 2016, 23, 673-681. [CrossRef]

270. Grembecka, J.; He, S.; Shi, A.; Purohit, T.; Muntean, A.G.; Sorenson, R.J.; Showalter, H.D.; Murai, M.J.; Belcher, A.M.; Hartley, T.; et al. Menin-MLL inhibitors reverse oncogenic activity of MLL fusion proteins in leukemia. Nat. Chem. Biol. 2012, 8, 277-284. [CrossRef]

271. Shi, A.; Murai, M.J.; He, S.; Lund, G.; Hartley, T.; Purohit, T.; Reddy, G.; Chruszcz, M.; Grembecka, J.; Cierpicki, T. Structural insights into inhibition of the bivalent menin-MLL interaction by small molecules in leukemia. Blood 2012, 120, 4461-4469. [CrossRef] [PubMed]

272. Dafflon, C.; Craig, V.J.; Méreau, H.; Gräsel, J.; Schacher Engstler, B.; Hoffman, G.; Nigsch, F.; Gaulis, S.; Barys, L.; Ito, M.; et al. Complementary activities of DOT1L and Menin inhibitors in MLL-rearranged leukemia. Leukemia 2017, 31, 1269-1277. [CrossRef] [PubMed]

273. Picaud, S.; Fedorov, O.; Thanasopoulou, A.; Leonards, K.; Jones, K.; Meier, J.; Olzscha, H.; Monteiro, O.; Martin, S.; Philpott, M.; et al. Generation of a Selective Small Molecule Inhibitor of the CBP/p300 Bromodomain for Leukemia Therapy. Cancer Res. 2015, 75, 5106-5119. [CrossRef] [PubMed]

274. Guenther, M.G.; Lawton, L.N.; Rozovskaia, T.; Frampton, G.M.; Levine, S.S.; Volkert, T.L.; Croce, C.M.; Nakamura, T.; Canaani, E.; Young, R.A. Aberrant chromatin at genes encoding stem cell regulators in human mixed-lineage leukemia. Genes Dev. 2008, 22, 3403-3408. [CrossRef] [PubMed]

275. Mak, A.B.; Nixon, A.M.L.; Moffat, J. The Mixed Lineage Leukemia (MLL) Fusion-Associated Gene AF4 Promotes CD133 Transcription. Cancer Res. 2012, 72, 1929-1934. [CrossRef]

276. Gardner, R.; Wu, D.; Cherian, S.; Fang, M.; Hanafi, L.-A.; Finney, O.; Smithers, H.; Jensen, M.C.; Riddell, S.R.; Maloney, D.G.; et al. Acquisition of a CD19-negative myeloid phenotype allows immune escape of MLL-rearranged B-ALL from CD19 CAR-T-cell therapy. Blood 2016, 127, 2406-2410. [CrossRef]

277. Sanjuan-Pla, A.; Bueno, C.; Prieto, C.; Acha, P.; Stam, R.W.; Marschalek, R.; Menéndez, P. Revisiting the biology of infant $\mathrm{t}(4 ; 11)$ /MLL-AF4+ B-cell acute lymphoblastic leukemia. Blood 2015, 126, 2676-2685. [CrossRef]

278. Li, D.; Hu, Y.; Jin, Z.; Zhai, Y.; Tan, Y.; Sun, Y.; Zhu, S.; Zhao, C.; Chen, B.; Zhu, J.; et al. TanCAR T cells targeting CD19 and CD133 efficiently eliminate MLL leukemic cells. Leukemia 2018, 32, 2012-2016. [CrossRef]

279. Bueno, C.; Velasco-Hernandez, T.; Gutiérrez-Agüera, F.; Zanetti, S.R.; Baroni, M.L.; Sánchez-Martínez, D.; Molina, O.; Closa, A.; Agraz-Doblás, A.; Marín, P.; et al. CD133-directed CAR T-cells for MLL leukemia: On-target, off-tumor myeloablative toxicity. Leukemia 2019, 33, 2090-2125. [CrossRef]

280. Moritz, L.E.; Trievel, R.C. Structure, mechanism, and regulation of polycomb-repressive complex 2. J. Biol. Chem. 2018, 293, 13805-13814. [CrossRef]

281. Zhao, Z.; Shilatifard, A. Epigenetic modifications of histones in cancer. Genome Biol. 2019, 20, 245. [CrossRef]

282. Okada-Iwabu, M.; Yamauchi, T.; Iwabu, M.; Honma, T.; Hamagami, K.; Matsuda, K.; Yamaguchi, M.; Tanabe, H.; Kimura-Someya, T.; Shirouzu, M.; et al. A small-molecule AdipoR agonist for type 2 diabetes and short life in obesity. Nature 2013, 503, 493-499. [CrossRef]

283. Akimoto, M.; Maruyama, R.; Kawabata, Y.; Tajima, Y.; Takenaga, K. Antidiabetic adiponectin receptor agonist AdipoRon suppresses tumour growth of pancreatic cancer by inducing RIPK1/ERK-dependent necroptosis. Cell Death Dis. 2018, 9, 1-18. [CrossRef]

284. Jiang, H. The complex activities of the SET1/MLL complex core subunits in development and disease. Biochim. Et Biophys. Acta (BBA) Gene Regul. Mech. 2020, 1863, 194560. [CrossRef]

285. Li, Y.; Han, J.; Zhang, Y.; Cao, F.; Liu, Z.; Li, S.; Wu, J.; Hu, C.; Wang, Y.; Shuai, J.; et al. Structural basis for activity regulation of MLL family methyltransferases. Nature 2016, 530, 447-452. [CrossRef]

286. Schapira, M.; Tyers, M.; Torrent, M.; Arrowsmith, C.H. WD40 repeat domain proteins: A novel target class? Nat. Rev. Drug Discov. 2017, 16, 773-786. [CrossRef]

287. Shah, K.K.; Whitaker, R.H.; Busby, T.; Hu, J.; Shi, B.; Wang, Z.; Zang, C.; Placzek, W.J.; Jiang, H. Specific inhibition of DPY30 activity by ASH2L-derived peptides suppresses blood cancer cell growth. Exp. Cell Res. 2019, 382, 111485. [CrossRef]

288. Yu, W.; Chory, E.J.; Wernimont, A.K.; Tempel, W.; Scopton, A.; Federation, A.; Marineau, J.J.; Qi, J.; Barsyte-Lovejoy, D.; Yi, J.; et al. Catalytic site remodelling of the DOT1L methyltransferase by selective inhibitors. Nat. Commun. 2012, 3, 1288. [CrossRef] 
289. Nicodeme, E.; Jeffrey, K.L.; Schaefer, U.; Beinke, S.; Dewell, S.; Chung, C.-W.; Chandwani, R.; Marazzi, I.; Wilson, P.; Coste, H.; et al. Suppression of inflammation by a synthetic histone mimic. Nature 2010, 468, 1119-1123. [CrossRef]

290. Singer, J.W.; Fleischman, A.; Al-Fayoumi, S.; Mascarenhas, J.O.; Yu, Q.; Agarwal, A. Inhibition of interleukin-1 receptor-associated kinase 1 (IRAK1) as a therapeutic strategy. Oncotarget 2018, 9, 33416-33439. [CrossRef]

Publisher's Note: MDPI stays neutral with regard to jurisdictional claims in published maps and institutional affiliations.

(C) 2020 by the authors. Licensee MDPI, Basel, Switzerland. This article is an open access article distributed under the terms and conditions of the Creative Commons Attribution (CC BY) license (http://creativecommons.org/licenses/by/4.0/). 